\title{
INTERACTION OF PEPTIDES RELATED TO ACTH, MSH AND $\beta$-LPH WITH NEUROTRANSMITTERS IN THE BRAIN
}

\author{
DiRK H. G. VersteEG \\ Rudolf Magnus Institute for Pharmacology, Medical Faculty, University of Utrecht, \\ Vondellaan 6, 3521 GD Utrecht, The Netherlands
}

\section{INTRODUCTION}

This review covers the literature on biochemical effects of peptides which are considered to be derived from pro-opiocortin (see Miller 1980; De Kloet et al., 1980), i.e. ACTH, $\alpha-\mathrm{MSH}$ and $\beta$-LPH and bioactive fragments of these three peptides, on the so-called classical neurotransmitters in the brain, viz. the catecholamines, acetylcholine, serotonin and $\gamma$-amino butyric acid (GABA). When overviewing the progress that has been made in the past decade, it becomes evident that two factors have had a crucial influence on the development of the strategies in this field of research. The first of these factors, which can be considered to have been of major importance, is the discovery of the existence in the mammalian central nervous system of peptide-containing neuronal systems, starting in the years 1974 and 1975 (for a recent review see: Hökfelt et al., 1980). In particular the discovery, isolation and characterization of Methionine 5 -enkephalin (Met-enkephalin; $\beta$-LPH $61-65)$ and $\beta$-endorphin $\left(\beta\right.$ - $\left.\mathrm{LPH}_{61-91}\right)$ (Hughes 1975; Hughes $e t$ al., 1975; Simantov and Snyder 1976; Teschemacher et al., 1975; $\mathrm{Li}$ and Chung 1976; Bradbury et al., 1976; for a more complete bibliography see: Miller 1980; De Kloet et al., 1980) have initiated an explosive expansion of the research concerning these endogenous opiate-like peptides, the results of which have contributed to the gradual development of the hypothesis that these and a variety of other peptides occurring in the brain within distinct neuronal systems, by acting as neuroregulators, are of essential importance for the homeostasis.

Neurochemical studies with ACTH, $x$-MSH and related peptides, it should be noted, have been carried out well before the discovery of neuronal systems in the brain containing these peptides. This can be ascribed mainly to the pioneering work of De Wied. which started in the early sixties and has led to the concept that ACTH and ACTHanalogs which are devoid of the classical endocrine effects of $\mathrm{ACTH}$, like $\mathrm{ACTH}_{1-10}$, $\mathrm{ACTH}_{4-10}$ and $\operatorname{Met}\left(\mathrm{O}_{2}\right)^{4}, \mathrm{D}-\mathrm{Lys}^{8}$. $\mathrm{Phe}^{9} \mathrm{ACTH}_{4-9}(\mathrm{ORG} 2766)$, exert their effects via an interaction with the brain (for reviews see: De Wied 1966; 1969; De Wied et al.. 1972; De Kloet and De Wied 1980; Bohus 1980; Van Nispen and Greven 1980). On basis of this concept a number of neurochemical studies have been carried out, mainly with $\mathrm{ACTH}_{4-10}$, which inhibits the extinction of active avoidance behavior, and its (D-Phe ${ }^{7}$ ) analog. which has an effect on the extinction of active avoidance behavior opposite to that of $\mathrm{ACTH}_{4-10}$, rather than with $\mathrm{ACTH}_{1-39}$ or $\mathrm{ACTH}_{1,24}$, which, in addition to their behavioral effects, have full adrenocorticotrophic activity (Van Nispen and Greven 1980). In most of these studies the peptides were administered systemically, which also was the route of administration in most of the behavioral studies (De Kloet and De Wied 1980; Bohus 1980). This is in contrast to the studies with the opioid peptides, which both in behavioral and in biochemical experiments are administered intracerebrally (see Sections 2, 3 and 4).

Another factor of importance, by its nature, has had, and in fact still has, a marked influence on the direction of the research on the effects of neuropeptides on brain neuro- 
transmitters. Here I am referring to the fact that the methodological developments and, hence, the possibilities to carry out adequate neurochemical experiments, have been very much dissimilar for the various classical neurotransmitters in the brain in the past decade. In the catecholamine field, for example, neuroanatomical research, primarily due to the availability of relatively specific and sensitive methods, has a long tradition. Moreover, for the catecholamines relatively adequate neurochemical methods have been available for a much longer time than has been the case for the other neurotransmitters. It therefore is logical that catecholamine research and, consequently, also the study of the possible interaction of neuropeptides with brain catecholamines has benefitted by this combination. Finally, the development of sensitive radiochemical methods for the measurement of neurotransmitters, their metabolites and the enzymes involved in their synthesis, has enabled researchers to go down in their experiments from whole brain or large brain parts to small brain parts and even individual brain nuclei. This has provided interesting new possibilities for approaching the question of how peptides interact with brain neurotransmitters at a high level of sensitivity.

The notion that peptides in the central nervous system are operating as neuroregulators, i.e. are participating in the functioning of the brain as neurotransmitters, neuromodulators or neurohormones (Barchas et al.. 1978; Barker 1978; Barker and Smith 1979) is supported by evidence coming from a variety of disciplines. In addition to (1) the immunocyto- and histochemical and radioimmunochemical data concerning their distribution and localization in the central nervous system and their occurrence in neuronal fiber systems, there are (2) the accumulating evidence, at least for some of these peptides, that they are being released from storage sites following nerve stimulation and that they are turning over, and data concerning (3) the presence in the brain for a number of them of specific binding sites with a regional distribution, (4) their effects on behavioral, neuroendocrine and autonomic processes, (5) their electrophysiological effects and (6) their effects on other brain neuroregulator systems. As was indicated before. this review will only deal with the biochemical effects of ACTH, $x-\mathrm{MSH}, \beta$-LPH and their derivatives, on other, and specifically the 'classical' neuroregulators in the brain. Since data from the other disciplines will be the subject of parallel reviews in this series, these will only be mentioned for the sake of clarity in selected cases. Hence, results of neuroanatomical studies showing a close association between peptidergic systems and, e.g.., catecholaminecontaining systems, though indicative for possible interactions between the two, will not be discussed. Neither will results be included of either studies in which the effects were measured of microinjections of peptides of the ACTH-, MSH- and $\beta$-LPH-series in brain regions rich in cell bodies or terminals of a particular transmitter on behavioral, neuroendocrine or autonomic parameters, or of studies concerning the effects of their microiontophoretic application in such regions on electrophysiological parameters.

Most of the neurochemical studies that have been undertaken so far were carried out in an attempt to relate effects of peptides on neurotransmitter metabolism with their effects on behavior or. in some cases, neuroendocrine processes. As has been mentioned before, for ACTH and $\alpha-\mathrm{MSH}$ and their analogs behavioral effects were mainly those on the acquisition and maintenance of avoidance behavior. The opioid peptides have mainly been studied in relation to their analgesic and cataleptic effects. although they also have been shown to affect other processes like, for instance, avoidance behavior (De Wied et al. 1978a, b), grooming behavior (Gispen et al., 1976), the release of pituitary hormones (Ferland et al.. 1977: Du Pont et al.. 1979; Holaday and Loh, 1979; Meites et al.. 1979; Taché et al.. 1979; Van Vugt et al., 1979). blood pressure regulation (Laubie et al., 1977; Bolme et al., 1978: Lemaire et al. 1978: Simon et al.. 1978; Bellet et al.. 1979; Fuxe et al., 1979b), thermoregulation (Bloom et al., 1976; Bläsig et al. 1978: Holaday et al., 1978; Clark, 1979; Lin et al., 1979; Scoto et al.. 1979) and food and water intake (Grandison and Guidotti 1977; Margules et al.. 1978; De Caro et al., 1979; King et al., 1979). The doses needed in order to induce analgesia are rather high when compared to those which affect some of the other processes mentioned above (De Wied et al., $1978 \mathrm{a}, \mathrm{b})$. It has been suggested that the action of LPH-analogs on some of these latter 
processes are mediated by receptor types which have characteristics different from those involved in the analgesic effects (De Wied et al., 1978a, b; Bohus 1980; Van Nispen and Greven 1980). It is therefore that, in many cases, the doses of the opioid peptides used in the various biochemical studies are mentioned.

In many of the studies reviewed here the effects of the opioid peptides on brain neurotransmitters are compared with those of morphine and other opiates and, not surprisingly, found to be similar. In this review the effects of the opiates will not be discussed. Reviews concerning the interaction of opiates with cholinergic (Domino 1979), catecholaminergic (Iwamoto and Way 1979) and serotoninergic and GABAergic (Brase 1979) systems in the brain have been published recently.

\section{ACTH AND RELATED PEPTIDES}

\subsection{Interaction with Brain Catecholamines}

The first attempts to obtain information concerning a possible involvement of brain catecholamines in the effects of ACTH and ACTH analogs on animal behavior were made some ten years ago. Both Weiss et al. (1970) and Hökfelt and Fuxe (1972), the former on basis of changes in the rate of disappearance of noradrenaline from the brain following synthesis inhibition with $\alpha$-methyl-p-tyrosine methylester ( $\alpha$-MPT), the latter on basis of changes in formaldehyde-induced catecholamine fluorescence following $\alpha$-MPT, suggested the existence of a correlation between the rate of extinction of conditioned avoidance behavior and central noradrenaline turnover. In other words, these authors suggested that an increased rate of extinction of a conditioned avoidance response was dependent on a decrease of the turnover of noradrenaline in the brain, whereas a decreased rate of extinction was related to an enhanced central noradrenaline turnover. Although this was an interesting working hypothesis, it can now be regarded to have been an oversimplification which was primarily based on the effects of hypophysectomy and adrenalectomy. Hypophysectomy, which decreases circulating ACTH to zero, and is associated with an increased rate of extinction of avoidance behavior (De Wied, 1966, 1969; Bohus 1980), causes a decreased brain noradrenaline turnover (Weiss et al., 1970; Fuxe et al., 1970; Versteeg et al., 1972; Hökfelt and Fuxe 1972; Van Loon 1973), whereas adrenalectomy, which increases circulating ACTH and is associated with a decreased rate of extinction of avoidance behavior (De Wied 1966, 1969; Bohus 1980), is accompanied by an increased noradrenaline turnover in the brain (Javoy et al., 1968; Weiss et al., 1970; Hökfelt and Fuxe (1972). According to the above mentioned suggestion, treatment with ACTH or ACTH fragments, which had been found to inhibit the extinction of avoidance behavior of intact rats (De Wied 1966, 1969; De Wied et al., 1972), should cause an acceleration of the turnover of noradrenaline in the brain. In fact, Hökfelt and Fuxe (1972) reported that ACTH indeed had been found to increase noradrenaline turnover in the hypothalamus, cortex and other brain regions of intact rats. However, whereas treatment of hypophysectomized rats with ACTH or ACTH fragments leads to an improvement of the capacity of these rats to acquire and maintain a conditioned avoidance response (De Wied, 1966, 1969; De Wied et al., 1972), such a treatment was reported to have no effect on central noradrenaline turnover of these rats (Fuxe et al., 1970), albeit that the dose used by these authors, 2.5-10 $\mathrm{mU} \mathrm{ACTH}_{1-24}$ per rat per day for three days, might have been too low.

Subsequently, it was found by Versteeg (1973) that $\mathrm{ACTH}_{4-10}$, which, like ACTH, inhibits the extinction of avoidance behavior (De Wied 1969; De Wied et al., 1972), increases noradrenaline turnover in whole brain and brain stem. (D-Phe)-ACTH $\mathrm{A}_{4-10}$, which has an effect on the extinction of avoidance behavior opposite to that of $\mathrm{ACTH}_{4-10}$ (De Wied 1969; De Wied et al., 1972), however, had no effect on noradrenaline turnover (Versteeg 1973). Leonard (1974) found the effects of $\mathrm{ACTH}_{4-10}$ and (D-Phe ${ }^{7}$ )-ACTH $\mathrm{AC}_{4-10}$ following chronic systemic administration to be qualitatively similar, in that the two peptides caused a slight but significant increase in whole brain 
noradrenaline turnover. The results of these two studies were certainly not in favour of the existence of a simple relationship between brain noradrenaline turnover and the performance of rats in tests of the acquisition and maintenance of a conditioned avoidance response.

In experiments in which the capacity of the brain to convert ${ }^{3} \mathrm{H}$-tyrosine into ${ }^{3} \mathrm{H}$-catecholamines was measured following semi-chronic peptide treatment, (two doses, 72 and $24 \mathrm{hr}$ before the measurement respectively), $\mathrm{ACTH}_{4-10}$ was found to increase whole brain and brain stem ${ }^{3} \mathrm{H}$-catecholamine synthesis (Versteeg and Wurtman, 1975). However, this effect could not be found following this same treatment either of rats that had been hypophysectomized 18 days before the first treatment, or on the day of the first treatment, or of rats that had been subjected to bilateral adrenalectomy 3 days before the first treatment or on the day of the first treatment (Versteeg and Wurtman, 1975). It should be noted that in the experiments with intact rats Versteeg and Wurtman (1975) measured the accumulation of total ${ }^{3} \mathrm{H}$-catecholamines; it is thus unclear, whether the effect is due to an increased synthesis of noradrenaline, of dopamine, or of both catecholamines. Using a similar treatment schedule, and comparable biochemical methods, Dunn and associates observed that in mice $\mathrm{ACTH}_{1-24}, \mathrm{ACTH}_{4-10}$ and (D-Phe ${ }^{7}-\mathrm{ACTH}_{4-10}$ caused an increase in the conversion of ${ }^{3} \mathrm{H}$-tyrosine into ${ }^{3} \mathrm{H}$-dopamine in the brain, but not into ${ }^{3} \mathrm{H}$-noradrenaline (Dunn et al., 1976; Iuvone et al., 1978). Interestingly, Iuvone et al. (1978) also found that $\mathrm{ACTH}_{4-10}$ was unable to affect the conversion of ${ }^{3} \mathrm{H}$-tyrosine into ${ }^{3} \mathrm{H}$-dopamine in the brains of rats that had been adrenalectomized $24 \mathrm{hr}$ before the first peptide administration.

Results of studies with $\alpha-\mathrm{MSH}\left(\left(\mathrm{N}\right.\right.$-acetylSer $\left.\left.{ }^{1}\right)-\mathrm{ACTH}_{1-13}\right)$, which contains the behaviorally active sequence of $\mathrm{ACTH}_{4-10}$, on $\alpha$-MPT-induced catecholamine disappearance in the brain of intact and hypophysectomized rats, led Kostrzewa et al. (1975) to conclude that a correlation between effects on behavioral parameters and effects on noradrenaline turnover in the brain did not appear to be very likely for $\alpha$-MSH. In agreement with the findings of Kostrzewa et al. (1975), Dunn et al. (1976) and luvone et al. (1978) observed no effects of either $\alpha$ - or $\beta$-MSH on the conversion of ${ }^{3} \mathrm{H}$-tyrosine into ${ }^{3} \mathrm{H}$-catecholamines in mouse brain. Taken together, it seems to be unresolved whether the effects of ACTH-like peptides, which all have the $\mathrm{ACTH}_{4-10}$ sequence in common on brain catecholamines is a direct one; it seems likely that factors of an as yet unidentified nature are involved.

Also the results of studies in which the effect of treatment with ACTH fragments was measured on regional tyrosine hydroxylase $(\mathrm{TH})$ activity in the brain, are conflicting. Initially, Dunn and associates reported that in mice treated for 3 days with $\mathrm{ACTH}_{4-10}$, striatal TH activity was $50-60 \%$ higher than that of vehicle-treated animals (Dunn et al., 1976). In a more extensive study however, Dunn et al. (1978) were unable to find any significant effect of this peptide, or of ORG2766, a protected $\mathrm{ACTH}_{4-9}$ derivative which has been shown to be very potent in behavioral tests (Van Nispen and Greven 1980; Bohus, 1980), on TH activity in mouse striatum or in any of the other brain parts studied. Van Loon et al. (1978b) reported that in rats hypophysectomized 14 days before decapitation, TH activities of the hypothalamus, pons-medulla and cerebellum were increased by approximately $20 \%$ over that of weight-matched controls, while TH activity of the striatum was unaffected. Chronic treatment of hypophysectomized rats with a low dose of $\mathrm{ACTH}_{1-24}(0.5 \mu \mathrm{g} / 100 \mathrm{~g}$ body weight, s.c. per day for 12 days) largely prevented the hypophysectomy-induced rise in TH activity of the hypothalamus, partly prevented the increase in the pons-medulla and had no effect on TH activity of the cerebellum and striatum (Van Loon et al., 1978b). Similarly, it was found that ACTH treatment of hypophysectomized rats counteracted the hypophysectomy-induced decrease in dopamine- $\beta$-hydroxylase activity of the hypothalamus and pons-medulla, but not of the cerebellum (Van Loon et al., 1978b). In contrast to these findings with hypophysectomized rats, however, Van Loon et al. (1978b) observed that treatment of intact rats with $\mathrm{ACTH}_{1-24}$ failed to produce any changes in regional TH activity in the brain. Again, therefore, it cannot be said that these data on effects and lack of effects of ACTH-related 
peptides on the enzymes involved in brain catecholamine synthesis form evidence in favour of a correlation between behavioral effects and effects on brain catecholamines of these peptides.

Whereas the results of the above described studies do not seem to support that the effect of ACTH analogs on brain catecholamine systems is a direct one, the results of Endröczi and associates seem to indicate the opposite. Intracerebroventricular (i.c.v.) administration of doses of $\mathrm{ACTH}_{1-24}$ and $\mathrm{ACTH}_{4-10}$ of 0.1 up till $5.0 \mu \mathrm{g}$ caused an increase in the rate of disappearance of i.c.v. administered ${ }^{3} \mathrm{H}$-noradrenaline from the hypothalamus, hippocampus and cortex of adrenalectomized rats (Endröczi et al., 1975; Endröczi 1976). Implantation of $\mathrm{ACTH}_{4-10}$ in the region of the locus coeruleus, but not in the septal region or in the medial forebrain bundle at the level of the posterior hypothalamus, also caused an increase in the disappearance of label from hippocampus, hypothalamus and cortex (Ecdröczi, 1977). These results implicate an effect of bio-active ACTH analogs at the level of the cell bodies of the dorsal noradrenergic bundle, which might be related to the effects of these peptides on behavior (Endröczi, 1977). It should be realized, however, that the degradation of i.c.v. injected ${ }^{3} \mathrm{H}$-noradrenaline is different from that of endogenous noradrenaline and also that ${ }^{3} \mathrm{H}$-noradrenaline can be taken up by other neurons than noradrenaline neurons as well.

Due to the technique employed, the work of Lichtensteiger and associates has a special and somewhat isolated position. In a pilot study Lichtensteiger et al. (1976) established that a close relationship exists between the mean fluorescence intensity of a given group of dopamine neurons, as measured by a microfluorometric procedure based on the formaldehyde-induced fluorescence method of Falck and Hillarp, and their firing rate; a rise in mean fluorescence intensity being accompanied by an increase in mean firing rate. Using this complicated but very sensitive technique Lichtensteiger and associates were able to study the effects of treatment with peptides on the functional state of groups of catecholamine neurons. Lichtensteiger and Lienhart (1977) observed that 30 min following the administration of $\alpha-\mathrm{MSH}$ in doses ranging from 10 to $100 \mu \mathrm{g} / \mathrm{kg}$, i.p. dopamine containing neurons in the arcuate nucleus and the substantia nigra responded with an increased firing rate. Comparable doses of $\mathrm{ACTH}_{1-24}$, on the other hand, were without effect (Lichtensteiger and Lienhart 1977). In a more recent study, Lichtensteiger et al. (1979) and Leichtensteiger and Monnet (1979) reported that arcuate nucleus dopamine neurons were activated following treatment of rats with $\alpha-\mathrm{MSH}$ and also after administration of its C-terminal tripeptide $\alpha-\mathrm{MSH}_{11-13}$, whereas little, if any, effect was seen with ORG2766, which has a high potency in affecting behavior but is devoid of MSH activity. On basis of these findings it was concluded (Lichtensteiger et al., 1979; Lichtensteiger and Monnet 1979) that the response of the arcuate nucleus dopamine neurons was related to activation of a neuroendocrine feedback loop involved in the regulation of MSH secretion. On the activity of dopamine neurons in the substantia nigra, however, ORG2766 was most potent in affecting dopamine fluorescence intensities (Lichtensteiger et al., 1979; Lichtensteiger and Monnet 1979). Obviously, several discrepancies need to be resolved, one of them being that ORG2766, particularly in the higher dose range $(5.0 \mu \mathrm{g} / \mathrm{kg})$, did cause a decrease rather than an increase in mean fluorescence intensity (Lichtensteiger et al., 1979), while $\mathrm{ACTH}_{1-24}$ had no effect and $x-\mathrm{MSH}$ increased dopamine fluorescence intensities (Lichtensteiger and Lienhart 1977). In any case, again there seems not to be a relationship with the behavioral effects of these three peptides as observed by De Wied and associates (De Wied 1966, 1969; De Wied et al., 1972; De Kloet and De Wied 1980; Bohus 1980).

In addition to the above mentioned data, which concern the results of studies in which the effects of various ACTH analogs were measured on dynamic aspects of brain catecholamine metabolism, a number of results has to be mentioned concerning the influence of $\mathrm{ACTH}$ and $\mathrm{ACTH}$ fragments on the concentration of catecholamines in whole brain, brain parts or microdissected brain nuclei. In several cases these data on catecholamine concentrations were by-products of measurements of the rate of turnover of catecholamines following synthesis inhibition with $x$-MPT (Versteeg 1973; Leonard 1974; Kostr- 
zewa et al., 1975). In those cases that levels of catecholamines were measured in whole brain (Versteeg 1973; Leonard 1974; Iuvone et al., 1978) or in brain parts (Versteeg 1973; Leonard 1974; Ramaekers et al., 1978; Kostrzewa et al., 1975) following chronic or semi-chronic treatment with ACTH analogs, not or only marginal effects were found. Telegdy and Kovács (1979a, b), however, observed an increased dopamine concentration in striatum and mesencephalon, but not in hypothalamus, septum and hippocampus, 30 min after the administration of $20 \mu \mathrm{g}$ ACTH per rat, i.p. while this treatment caused a decrease in the concentration of noradrenaline in septum and hippocampus, but not in the other three brain parts. Using a sensitive radio-enzymatic catecholamine assay, Fekete et al. $(1975,1978)$ measured the effects of acute ACTH administration on catecholamine levels of brain nuclei dissected as described by Palkovits (1973). In their first paper, Fekete et al. (1975) reported that $30 \mathrm{~min}$ after $30 \mu \mathrm{g}$ ACTH the dopamine concentration of the median eminence and the noradrenaline concentration of the supraoptic nucleus were increased, whereas the dopamine concentration of the locus coeruleus was decreased; $3 \mathrm{hr}$ after ACTH administration the noradrenaline level was elevated in the locus coeruleus and decreased in the supraoptic nucleus, while the dopamine concentration of the arcuate nucleus was decreased. In a subsequent paper (Fekete et al., 1978) no changes were reported to occur in the dopamine concentration of any of the 12 brain regions $3 \mathrm{hr}$ after ACTH administration. The noradrenaline concentration of the locus coeruleus was increased at that time; that of the arcuate nucleus and the ventromedial nucleus decreased (Fekete et al., 1978). Apart from the apparent lack of consistency, another problem with these results is their interpretation. Absence of differences in catecholamine concentrations following peptide and vehicle treatment does not necessarily include the absence of differences in turnover or synthesis, as is indicated by the results of Versteeg (1973), Leonard (1974), Kostrzewa et al. (1975) and Iuvone et al. (1978). On the other hand, if changes in catecholamine concentrations are found, it is not possible, without additional data, to ascribe the change in concentration to either an increased or a decreased neuronal activity.

\subsection{Interaction with Brain ACetylcholine}

Following i.c.v. administration, $\mathrm{ACTH}_{1-24}$ and $\alpha-\mathrm{MSH}$, in a dose of $10 \mu \mathrm{g}$ per rat, have been found to induce an increase in hippocampal acetylcholine turnover (Wood et al., 1978). No effects were evident on acetylcholine turnover in cortex, striatum and diencephalon, while on the turnover of brain stem acetylcholine only $\alpha$-MSH had effects (Wood et al., 1978). In these experiments the turnover of acetylcholine was measured by infusing i.v. phosphoryl- $\left({ }^{2} \mathrm{H}_{9}\right)$ choline in a rate of $15 \mu \mathrm{mol}$ per min for $9 \mathrm{~min}$ starting $21 \mathrm{~min}$ after the i.c.v. administration of the peptide, and then, after decapitation of the rat, calculating the ${ }^{2} \mathrm{H}$ enrichment of choline and acetylcholine as measured by means of mass fragmentography (Zsilla et al., 1977). ACTH $_{1-24}, x-\mathrm{MSH}$ and a number of analogs of these peptides have been found to induce a stretching and yawning syndrome which is preceded by excessive grooming (for references see Wood et al., 1978; Gispen and Isaacson 1980). On basis of the fact that this stretching and yawning syndrome can be prevented by centrally acting anticholinergic drugs (Ferrari et al., 1963), Wood et al. (1978) suggest that the effect of $\mathrm{ACTH}_{1-24}$ and $\alpha-\mathrm{MSH}$ on stretching and yawning which they observe might be related to the effects of these peptides on hippocampal acetylcholine turnover. Interestingly, ORG2766, which, as was mentioned before, is very potent in facilitating the retention of conditional avoidance behavior, fails both to induce stretching and yawning and to affect hippocampal acetylcholine turnover (Wood et al., 1978). It should be noted, however, that brain dopamine and in particular the nigrostriatal and mesolimbic dopamine systems have been implicated in the excessive grooming elicited by i.c.v. administration of $\mathrm{ACTH}_{1-24}, \alpha-\mathrm{MSH}$ and a number of analogs, e.g. $\mathrm{ACTH}_{1-16}$ and (D-Phe $\left.{ }^{7}\right)-\mathrm{ACTH}_{4-10}$, but not $\mathrm{ACTH}_{4-10}$ (Wiegant et al., 1977; Cools et al., 1978).

In further experiments Wood et al. (1979) showed that 2 to 3 weeks after surgical 
transsection of the projections from the cingulum or the entorhinal cortex to the hippocampus $\mathrm{ACTH}_{1-24}$ and $x$-MSH still can enhance hippocampal acetylcholine turnover. Neither lesioning of the arcuate nucleus, which contains the cell bodies of the ACTH/MSH system, nor acute transsection of the fimbria interfered with the effects of the peptides on hippocampal acetylcholine turnover (Wood et al., 1979). On the basis of these findings and on the finding that intraseptal injection of $\mathrm{ACTH}_{1-24}$ or $\alpha-\mathrm{MSH}$ failed to affect hippocampal acetylcholine turnover Wood et al. (1979) suggest that these peptides exert their stimulating effect on the turnover of acetylcholine in the hippocampus by activating receptors located in the hippocampus.

\subsection{Interaction with Brain Serotonin}

While many papers have been published reporting effects of ACTH analogs on brain catecholamines, few data are available on effects of this group of peptides on brain serotonin. Leonard (1974) found that chronic treatment with $\mathrm{ACTH}_{4-10}$ or $\left(\mathrm{D}-\mathrm{Phe}^{7}\right)-\mathrm{ACTH}_{4-10}(10 \mu \mathrm{g}$ for 13 days) resulted in a decrease in the concentration and turnover of serotonin in the rat brain. In a more recent paper Leonard et al. (1976) reported an increased conversion of ${ }^{3} \mathrm{H}$-tryptophan into ${ }^{3} \mathrm{H}$-serotonin in rat cortex, but not in other brain regions, following chronic treatment with $\alpha$-MSH. Spirtes et al. (1975), on the other hand, found no effect of $\alpha$-MSH on serotonin concentration and serotonin turnover in the brains of intact rats, while serotonin accumulation after pargyline was decreased in the cortex of hypophysectomized rats following treatment with $x-\mathrm{MSH}$. Acute effects of ACTH (20 $\mu \mathrm{g}$ per rat, $30 \mathrm{~min}$ prior to decapitation) were observed on the serotonin concentration of the hypothalamus, mesencephalon and hippocampus by Telegdy and Kovács (1979a; 1979b). Again, like the case with the catecholamines, it can be concluded that there is no convincing evidence among the available data for a correlation between effects of ACTH-like peptides on serotonin metabolism in the brain and the effects of these peptides on behavior. The results of a study by Ramaekers et al. (1978) seem to be the only exception. These authors, comparing the content of noradrenaline, dopamine and serotonin in a number of brain regions of the rat in relation to passive avoidance training and treatment with $\mathrm{ACTH}_{4-10}$ and (D-Phe $\left.{ }^{7}\right)-\mathrm{ACTH}_{4-10}$, found that changes in hippocampal serotonin levels, but not in other brain parts or in catecholamine levels in any of the brain parts studies, were correlated to the changes in passive avoidance behavior after the administration of the analogs (Ramaekers et al., 1978). An obvious criticism of this work however, is that, since catecholaminergic activity can be subject to considerable changes in the absence of changes in catecholamine levels, the measurement of catecholamine concentrations only can easily lead to false negative conclusions.

\section{ENKEPHALINS}

\subsection{Interaction With Brain Catecholamines}

A relatively large number of data is available concerning effects of Met-enkephalin and its more stable synthetic analogs, administered in doses which are known to cause analgesia and catalepsy, on striatal dopamine in the rat. Effects have been described on (1) homovanillic acid (HVA) and 3,4-dihydroxyphenyl-acetic acid (DOPAC) levels, (2) the accumulation of these two dopamine metabolites following probenecid administration, (3) the rate of disappearance of dopamine following inhibition of its synthesis, (4) the conversion of ${ }^{3} \mathrm{H}$-tyrosine into ${ }^{3} \mathrm{H}$-dopamine and (5) the accumulation of 3,4-dihydroxyphenylalanine (DOPA) following inhibition of DOPA-decarboxylase with NSD 1015. In addition to this, effects have been reported on $\mathrm{K}^{+}$-induced release of ${ }^{3} \mathrm{H}$-dopamine from striatal slices in vitro. Though the results in many instances are unequivocal, the majority of these data support the notion that the enkephalins increase dopamine metabolism in this brain part. In agreement with the fact that analogs like D-Ala ${ }^{2}$-Met-enkephalinamide are more resistant to enzymatic degradation than the naturally occurring enkepha- 
lins, effective doses of these stable peptides are considerably lower than those of e.g. Met-enkephalin.

Loh et al. (1976) reported that, whereas $\beta$-endorphin had an inhibitory influence on ${ }^{3} \mathrm{H}$-dopamine release from striatal slices induced by potassium ions in a concentration of $53 \mathrm{~mm}$, under these conditions Met-enkephalin in concentrations as high as $10^{-4} \mathrm{M}$ was ineffective in doing so. Using similar experimental conditions however, Subramanian et al. (1977), found that Met-enkephalin in concentrations of $10^{-6}$ and $10^{-5} \mathrm{M}$ significantly diminished the $\mathrm{K}^{+}$-induced $(40 \mathrm{~mm})$ release of ${ }^{3} \mathrm{H}$-dopamine from striatal slices in vitro, an effect which could be blocked by naloxone. The reason for this discrepancy is not known, although it has been suggested that the $\mathrm{K}^{+}$-concentration used by Loh et al. (1976) might be aphysiologically high (cf. Arbilla and Langer, 1977).

Algeri et al. (1977) found that $45 \mathrm{~min}$ after the i.c.v. administration of D-Ala ${ }^{2}$-Metenkephalinamide in doses of 25 or $50 \mu \mathrm{g}$ per rat striatal HVA concentrations were increased significantly; following $10 \mu \mathrm{g}$ per rat striatal HVA levels were not significantly elevated, neither were DOPAC levels after any of the doses. In contrast, no differences were observed in striatal HVA content either $15 \mathrm{~min}$ after the i.c.v. administration of $100 \mu \mathrm{g}$ Met-enkephalin or $30 \mathrm{~min}$ after two doses of $100 \mu \mathrm{g}$ of this peptide given with a 15 min interval (Algeri et al., 1977). Similarly, Berney and Hornykiewicz (1977) found no effect on striatal HVA concentrations after the i.c.v. administration of $100 \mu \mathrm{g}$ Met-enkephalin. Although this difference in effectiveness to elevate striatal HVA levels between Met-enkephalin and the D-Ala ${ }^{2}$ analog might be due, as was suggested by Algeri et al. (1977; Calderini et al., 1978), to the difference in susceptibility of the two peptides to enzymatic degradation, it obviously cannot be excluded that other factors have to be taken into account. Using a similar experimental design, Biggio et al. (1978a) found that doses of D-Ala ${ }^{2}$-Met-enkephalinamide as low as 1.5 or $3.0 \mu \mathrm{g}$ per rat i.c.v. caused a significant increase in the levels of both HVA and DOPAC in the caudate nucleus, while doses of Met-enkephalin of 50 or $100 \mu \mathrm{g}$ per rat resulted in elevations of the content of the dopamine metabolites of an order of magnitude comparable to that after 1.5-3.0 $\mu \mathrm{g}$ of the D-Ala ${ }^{2}$-analog. It was also found that naloxone, given i.p. at the same time as the peptides were administered i.c.v., competely antagonized the effects of both Met-enkephalin and D-Ala ${ }^{2}$-Met-enkephalinamide on caudate HVA and DOPAC concentrations (Biggio et al., 1978a). Injections of D-Ala ${ }^{2}$-Met-enkephalinamide directly into the caudatus also caused an increase of the DOPAC content in this nucleus, demonstrating that the caudate is the site of action of the peptide (Biggio et al., 1978a). The D-Ala ${ }^{2}$ analog, given in doses of 3.0 or $6.0 \mu \mathrm{g}$ i.c.v. caused an increase in the accumulation of DOPA in the caudate nucleus following DOPA-decarboxylase inhibition with NSD 1015 (Biggio et al., 1978a), an effect which has also been observed in the striatum with very high doses of Met- and Leu-enkephalin (Magnusson et al., 1979) and with the enkephalin analogs D-Ala ${ }^{2}$-Met-enkephalinamide (Magnusson et al., 1979: Garcia-Sevilla et al., 1980) and D-Ala ${ }^{2}-\mathrm{MePhe}^{4}-\mathrm{Met}(\mathrm{O})^{5}$-ol-enkephalin (FK 33-824) (Garcia-Sevilla et al., 1980) at a much lower dose level. On basis of their data, Biggio et al. (1978a) concluded that the enkephalins cause an elevation of dopamine synthesis by activating opioid receptors in the caudate nucleus. Since the prior destruction of caudate neurons postsynaptic to the nigrostriatal dopamine terminals did not prevent the effect of D-Ala ${ }^{2}$-Met-enkephalinamide either on DOPAC content or on DOPA accumulation following NSD 1015, it was also concluded that the peptide exerts its effect on caudate dopamine synthesis via an action on opioid receptors located on the dopamine terminals rather than on postsynaptic structures (Biggio et al., 1978a, b).

The suggestion that the opioid receptors exerting an influence on caudate nucleus dopamine metabolism are located on the dopamine terminals of nigrostriatal neurons is further supported by the results of studies in which the binding of different radiolabeled ligands for opioid binding sites was measured to striatal membranes obtained from rats that had been subjected to various chemical or electrical lesions. Thus, it was shown that degeneration of caudate nucleus terminal, either by i.c.v. 6-hydroxydopamine (6-OHDA) administration or by electrocoagulation of the pars compacta of the substantia nigra. 
resulted in approximately $30 \%$ decrease in ${ }^{3} \mathrm{H}$-Leu-enkephalin and/or ${ }^{3} \mathrm{H}$-naloxone binding in the striatum (Pollard et al., 1977). This, combined with the finding that not more than a $30-40 \%$ decrease in ${ }^{3} \mathrm{H}$-Leu-enkephalin binding was observed after transsection of the nigrostriatal dopamine pathway at the level of the hypothalamus (Pollard et al., 1978), indicates that not more than one-third of the opioid receptors in the striatum is located on dopamine terminals, while the remaining two-thirds are supposed to be located on neurons intrinsic to or projecting from this structure (Pollard et al., 1977. 1978; Schwartz et al., 1978, 1979). Similar results were reported by Carenzi et al. (1978) and Trabucchi et al. (1979), using ${ }^{3} \mathrm{H}-\mathrm{D}-\mathrm{Ala}^{2}$-Met-enkephalinamide binding following various lesions.

Data concerning effects of enkephalin analogs on striatal dopamine turnover and on the striatal conversion of ${ }^{3} \mathrm{H}$-tyrosine into ${ }^{3} \mathrm{H}$-dopamine, although in many cases fitting with the concept of an enhanced dopamine metabolism, are sometimes conflicting. Using the in vivo capacity of the striatum to convert ${ }^{3} \mathrm{H}$-tyrosine into ${ }^{3} \mathrm{H}$-dopamine, Calderini et al. (1978) found that, whereas D-Ala ${ }^{2}$-Met-enkephalinamide, injected i.c.v. in a dose of $10 \mu \mathrm{g}$ per rat, caused a significant increase in striatal dopamine synthesis, Met-enkephalin, in a dose of $200 \mu \mathrm{g}$ per rat administered via the same route, caused a significant decrease. Similarly. DOPAC and tritiated DOPAC concentrations were decreased after injection of Met-enkephalin and increased when the $\mathrm{D}-\mathrm{Ala}^{2}$ analog had been administered; the concentration of ${ }^{3} \mathrm{H}-3$-methoxytyramine, however, was decreased after Met-enkephalin, but not affected after D-Ala ${ }^{2}$-Met-enkephalinamide administration (Calderini et al., 1978). This latter observation, according to Calderini et al. (1978), is in agreement with the assumption that D-Ala ${ }^{2}$-Met-enkephalinamide acts mainly on intraterminal dopamine synthesis, while dopamine release is decreased (cf. Subramanian et al., 1977).

Based on the fact that following Met-enkephalin administration the level of cold tyrosine and tritiated tyrosine is markedly elevated in the striatum, Calderini et al. (1978) postulated that the effect of Met-enkephalin on striatal dopamine synthesis might be an artifact caused by the rapid release of the tyrosine residue from the injected peptide by intracerebral enzymatic degradation (cf. Hambrook et al., 1976; Meek et al., 1977; see also De Kloet et al., 1980). Recently. Garcia-Sevilla et al. (1980) reported that both Met-enkephalin and Leu-enkephalin, but not D-Ala ${ }^{2}$-Met-enkephalinamide and D-Ala ${ }^{2}$ $\mathrm{MePhe}^{4}$-Met $(\mathrm{O})^{5}$-ol-enkephalin, caused a marked increase of the tyrosine concentration in limbic regions, hemispheres, diencephalon and lower brain stem, while the effect in the striatum was much less pronounced. Anyhow, since Met-enkephalin, but not its D-Ala ${ }^{2}$ analog, was found to cause a decrease in the conversion of ${ }^{3} \mathrm{H}$-tyrosine into ${ }^{3} \mathrm{H}$ - noradrenaline also in the cortex (Calderini et al., 1978), the explanation of these authors seems to be a tenable one. Nevertheless, the final proof, e.g. by measuring the effect of an amount of tyrosine equivalent to that set free from $200 \mu \mathrm{g}$ Met-enkephalin on ${ }^{3} \mathrm{H}$-catecholamine synthesis, was not given.

Striatal dopamine turnover, as measured from the rate of dopamine disappearance following inhibition of tyrosine hydroxylase with $x$-MPT, was found to be increased after the i.c.v. administration of $25 \mu \mathrm{g}$ D-Ala ${ }^{2}$-Met-enkephalinamide (Calderini et al., 1978) and D-Ala ${ }^{2}$-D-Leu ${ }^{5}$-enkephalin (Deyo et al., 1979). Schwarcz et al. (1979), on the other hand, reported that Met-enkephalin, given as an i.c.v. infusion of approximately $50 \mu \mathrm{g}$ over a period of one hr in a total volume of $60 \mu \mathrm{l}$, did not affect the $\alpha$-MPT-induced disappearance of dopamine fluorescence from dopamine terminals in the caudate nucleus. Using the considerably lower dose of $100 \mathrm{ng}$ Met-enkephalin per rat. i.c.v. Versteeg et al. (1978) found no effect of this peptide on the $x$-MPT-induced disappearance of dopamine from either the caudate nucleus or the nucleus accumbens, though there were effects in other brain regions. In a recent paper Garcia-Sevilla et al. (1980) reported that after inhibition of DOPA-decarboxylase with benserazide the disappearance of dopamine was enhanced following the i.c.v. administration of $500 \mu \mathrm{g}$ of either Met- or Leu-enkephalin. Similar results were obtained with D-Ala ${ }^{2}$-Met-enkephalin $(50 \mu \mathrm{g})$ and D-Ala ${ }^{2}$ MePhe ${ }^{4}$-Met $(\mathrm{O})^{5}$-ol-enkephalin $(1 \mu \mathrm{g})($ Garcia-Sevilla et al., 1980). Differences in dose 
level seem to be the most plausible explanation for the observed differences in effectiveness of Met-enkephalin in eliciting changes in dopamine disappearance following synthesis inhibition.

The majority of the above described data can be considered to be compatible with the suggestion of Pollard et al. (1978) and Schwartz et al. (1978) that the primary effect resulting from the activation by enkephalins of opioid receptors localized presynaptically on dopamine terminals in the striatum is a decrease in dopamine release, which accounts for the various symptoms of decreased dopaminergic transmission observed immediately after their administration; secondary to this effect the interaction of the enkephalins causes an increased dopamine synthesis, due to a diminished feedback inhibition of presynaptic dopamine receptors, as can be demonstrated by increases in various parameters estimating dopamine synthesis. However, it is likely that additional mechanisms are involved in the interaction of enkephalins with striatal dopamine activity, as is indicated by Biggio et al. (1978a) and Algeri et al. (1978a; 1979).

Whereas an abundance of data is available concerning the effects of enkephalin analogs on striatal dopamine metabolism, less is known concerning effects on catecholamines in other brain regions. The first evidence for an interaction of enkephalins with brain catecholamines dates from 1976, when Taube et al. (1976) reported that Metenkephalin, in concentrations of $10^{-5}$ down to $10^{-7} \mathrm{M}$, diminished the release of label evoked by electrical field stimulation or by $20 \mathrm{~mm} \mathrm{~K}{ }^{+}$from slices of rat occipital cortex preloaded with ${ }^{3} \mathrm{H}$-noradrenaline. This effect was antagonized by naloxone, but not by the $\alpha$-blocker phentolamine (Taube et al., 1976). It was concluded that Met-enkephalin reduces transmitter release from cortical noradrenergic terminals, and that one function of endogenous opioid peptides might be the presynaptic inhibition of central noradrenergic neurotransmission (Taube et al., 1976). Recently, these findings were corroborated by Göthert et al. (1979), who found that ${ }^{3} \mathrm{H}$-noradrenaline release promoted by $30 \mathrm{~mm} \mathrm{~K}{ }^{+}$ from cortical and also from hypothalamic slices was decreased by Met-enkephalin at a concentration of $10^{-6} \mathrm{M}$.

Studies on effects of enkephalin analogs on in vivo catecholamine metabolism, as was the case with those on effects on striatal dopamine, have been carried out using a variety of methods, injection schedules, doses and dissection procedures. D-Ala ${ }^{2}$-Met-enkephalinamide, $25 \mu \mathrm{g}$ per rat administered i.c.v. increased the accumulation of DOPAC and HVA following probenecid and the conversion of ${ }^{3} \mathrm{H}$-tyrosine into ${ }^{3} \mathrm{H}$-dopamine in a brain region consisting of the nucleus accumbens, the tuberculum olfactorium and the amygdala (Calderini et al., 1978). Schwarcz et al. (1979) found that an i.c.v. infusion of Met-enkephalin causes an increase in the $\alpha$-MPT-induced disappearance of dopamine from the tuberculum olfactorium and the anterior part of the nucleus accumbens. D-Ala ${ }^{2}$-Met-enkephalinamide administered i.c.v. in a dose of $25 \mu \mathrm{g}$, according to Calderini et al. (1978) and Algeri et al. (1978a), does not affect either the rate of disappearance of noradrenaline after synthesis inhibition or the conversion of ${ }^{3} \mathrm{H}$-tyrosine into ${ }^{3} \mathrm{H}$-noradrenaline in the cortex. Higher doses, however, appear to be effective, as was shown by Garcia-Sevilla et al. (1980). These authors found that the enkephalin analogs D-Ala ${ }^{2}$ Met-enkephalin and D-Ala ${ }^{2}-\mathrm{MePhe}^{4}-\mathrm{Met}(\mathrm{O})^{5}$-ol-enkephalin dose dependently (4-256 $\mu \mathrm{g}$ for the former peptide; $0.003-1 \mu \mathrm{g}$ for the latter) increased the accumulation of DOPA following NSD 1015 in the hemispheres and also in limbic regions, diencephalon and lower brain stem. Large doses of Met-enkephalin and Leu-enkephalin (500 $\mu \mathrm{g}$ per rat, i.c.v.) were needed in order to obtain a significant effect on this parameter (Garcia-Sevilla et al., 1980).

The $x$-MPT-induced disappearance of dopamine from the cortex and from the median eminence was found to be decreased by D-Ala ${ }^{2}$-D-Leu ${ }^{5}$-enkephalin by Deyo et al. (1979). This latter observation is in accordance with results of a microfluorometric study by Ferland $e$ t al. (1977) of the $\alpha$-MPT-induced disappearance of formaldehyde-induced catecholamine fluorescence from substructures of the median eminence. These authors observed, using an administration schedule identical to that described above for the study by Schwarcz et al. (1979), a reduction in the disappearance of catecholamine 
fluorescence from the medial pallisade zone of the median eminance, which contains dopamine and noradrenaline terminals, and from the lateral pallisade zone, which contains mainly dopamine terminals. It has been suggested that this reduction of dopamine turnover in the median eminence is related to the effect of the opioid peptides on prolactin release from the pituitary (see Ferland et al., 1977; Deyo et al., 1979; also for references), which effect, as such, falls outside the scope of this review.

Using a much lower dose of Met-enkephalin (100 ng per rat) Versteeg et al. (1978) found the $\alpha$-MPT-induced disappearance of noradrenaline to be enhanced in the medial preoptic nucleus and the central amygdaloid nucleus, and to be decreased in the ventral central gray and the $\mathrm{A} 2$ region of the nucleus tractus solitarii, while the disappearance of dopamine was increased in the arcuate nucleus and the dorsal central gray. Taken together, it is evident that, as far as effects of enkephalins on catecholamine metabolism in brain regions other than the striatum are concerned, our knowledge is only fragmentary. Also, in many cases the significance of the observed changes is, as yet, obscure.

\subsection{Interaction with Brain ACETylcholine}

Met-enkephalin, in concentrations of $10^{-6}$ and $10^{-5} \mathrm{M}$, has been found to reduce the $\mathrm{K}^{+}$-induced release in vitro of radioactivity from hippocampal slices preloaded with ${ }^{3} \mathrm{H}$-acetylcholine, by incubating the slices with labeled choline (Subramanian et al. (1977). This effect, again, was prevented by naloxone (Subramanian et al., 1977). Using an in vivo cup technique, Jhamandas et al. (1977) obtained similar results for the spontaneous release or cortical acetylcholine. Both Met-enkephalin and Leu-enkephalin, given i.c.v. in a dose of $10 \mu \mathrm{g}$. were found to reduce acetylcholine release significantly, an effect which was counteracted by the subsequent administration of naloxone and prevented by the prior administration of this drug (Jhamandas et al., 1977).

The situation in the striatum seems to be more complicated, as is indicated by the results of Vizi et al. (1977) and Harsing et al. (1978). Met-enkephalin methypester and D-Met ${ }^{2}$-Pro ${ }^{5}$-enkephalinamide (Harsing et al., 1978) and D-Ala ${ }^{2}-$ Pro $^{5}$-enkephalinamide (Vizi et al., 1977; Harsing et al., 1978) all caused an increase in ouabain-induced acetylcholine release from rat striatal slices. The effect of these peptides was prevented by naloxone (Vizi et al., 1977). However, enkephalin analogs inhibited, rather than increased, the release of acetylcholine from striatal slices of rats which had been pretreated with i.c.v. 6-OHDA in doses that cause a destruction of the nigro-striatal dopamine system (Vizi et al., 1977). It was suggested that the effect of enkephalin analogs on acetylcholine release from striatal tissue from intact rats should be ascribed to their decreasing influence on dopamine release from neurons that have an inhibitory control on striatal cholinergic interneurons (Vizi et al., 1977). That enkephalins reduce acetylcholine release from striatal slices of 6-OHDA-pretreated rats indicates that activation of opioid receptors located on the striatal cholinergic neurons might be involved in modulating acetylcholine release, according to Vizi et al. (1977) and Harsing et al. (1978), in a way similar to that of hippocampal (Subramanian et al., 1977) and cortical (Jhamandas et al., 1977) cholinergic neurons.

\subsection{Interaction with Brain Serotonin}

Whole brain serotonin metabolism appears to be enhanced following high i.c.v. doses of Met-enkephalin, as can be seen from the finding by Laska and Fennessy (1978) of an increased 5-HIAA level $3 \mathrm{~min}$ after $150-600 \mu \mathrm{g}$ of the peptide and by Magnusson et al. (1979) of an increased accumulation of 5-HTP after NSD 1015 administration following $500 \mu \mathrm{g}$ Met-enkephalin. The latter authors also found that Leu-enkephalin, in the same dose as that of Met-enkephalin, and D-Ala ${ }^{2}$-Met-enkephalinamide. in doses of 4 to $250 \mu \mathrm{g}$. had effects similar to that of Met-enkephalin (Magnusson et al., 1979). Algeri et al. $(1978 \mathrm{c})$, in a study on the effects of D-Ala ${ }^{2}$-Met-enkephalinamide on brain serotonin metabolism, observed that whole brain 5-HIAA levels in whole brain were elevated 45,90 
and $135 \mathrm{~min}$ after the i.c.v. administration of this peptide. In addition, Algeri et al. (1978c) observed that this dose caused an increase in the accumulation of 5-HIAA in the limbic forebrain following probenecid, but not in the striatum of the rat (see also Algeri et al., 1978b). These effects of the D-Ala ${ }^{2}$ analog were completely counteracted by the prior administration of naloxone, which points at the involvement of opioid receptors in the effects of the peptide on limbic serotonin metabolism (Algeri et al., 1978b, c).

In an extensive follow-up of the study by Magnusson et al. (1979), in a recent paper Garcia-Sevilla et al. (1980) describe the effects of various enkephalin analogs on regional serotonin metabolism in the rat brain. Met-enkephalin and Leu-enkephalin $(500 \mu \mathrm{g}$ per rat, i.c.v.) both enhanced the formation of 5-HTP in diencephalon and lower brain stem of NSD 1015-pretreated rats. Met-enkephalin caused a small but significant increase in striatum and hemispheres, but not in the limbic forebrain; Leu-enkephalin was ineffective in the latter three brain regions. D-Ala ${ }^{2}$-Met-enkephalinamide, in a dose of $125 \mu \mathrm{g}$ per rat, i.c.v. had effects of the same order of magnitude as that of Met-enkephalin in the diencephalon and lower brain stem. but was more effective in enhancing 5-HTP accumulation in limbic forebrain, striatum and hemispheres. A lower dose of the D-Ala ${ }^{2}$-analog was not effective. D-Ala ${ }^{2}-\mathrm{MePhe}^{4}$-Met $(\mathrm{O})^{5}$-ol-enkephalin, $1 \mu \mathrm{g}$ per rat, caused a moderate increase in 5-HTP formation in all five brain regions. Met- and Leu-enkephalin $(500 \mu \mathrm{g})$ and also D-Ala ${ }^{2}$-Met-enkephalinamide $(50 \mu \mathrm{g})$ caused a decrease in the 5-HT level in the brain of benserazide-pretreated rats. After Met-enkephalin $(500 \mu \mathrm{g})$ and D-Ala ${ }^{2}-\mathrm{MePhe}^{4}(\mathrm{O})^{5}$-ol-enkephalinamide $(1 \mu \mathrm{g})$ brain 5-HIAA levels of benserazide-pretreated rats were increased. Though the above mentioned results suggest that enkephalins are participating in the regulation of the activity of serotonin-containing systems in the brain, the localization of the receptors and the circuitry involved remains to be elucidated.

\section{ENDORPHINS}

\subsection{Interaction with Brain Catecholamines}

Like the case with the enkephalins, the first data concerning biochemical effects of endorphins on brain neurotransmitters were on $\mathrm{K}^{+}$-induced release of label from brain slices preloaded with tritiated catecholamines in vitro. In 1976 Loh et al. reported that $\beta$-endorphin $\left(\beta-\mathrm{LPH}_{61-91}\right)$ dose dependently inhibited the $\mathrm{K}^{+}$-stimulated release of ${ }^{3} \mathrm{H}$-dopamine from superfused striatal slices; the effect was obtained with a $\mathrm{K}^{+}$concentration of $53 \mathrm{~mm}$ and was antagonized by naloxone. It was in this same paper that Loh et al. (1976) reported that Met-enkephalin failed to affect the $\mathrm{K}^{+}$-induced release of ${ }^{3} \mathrm{H}$-dopamine from striatal slices (see Section 3.1.). In experiments in which a $\mathrm{K}^{+}$concentration of $20 \mathrm{~mm}$ was used, which can be considered to be a more physiological condition, Arbilla and Langer (1978), however, were unable to find any effect of $\beta$-endorphin or morphine on the release of ${ }^{3} \mathrm{H}$-dopamine from striatal slices. Under the same experimental conditions $\beta$-endorphin was found to diminish the $\mathrm{K}^{+}$-induced release of ${ }^{3} \mathrm{H}$-noradrenaline by slices from rat occipital cortex (Arbilla and Langer, 1978).

Data on effects on $\beta$-endorphin on in tito parameters of striatal dopamine metabolism, like the conversion of ${ }^{3} \mathrm{H}$-tyrosine into ${ }^{3} \mathrm{H}$-dopamine and the $x$-MPT-induced disappearance of dopamine, also are not without conflict. Izumi et al. (1977) found no significant effect of $\beta$-endorphin, injected i.c. $v$. in a dose of $50 \mu \mathrm{g}$, on the $\alpha$-MPT-induced disappearance of dopamine from the striatum. On the other hand, Fuxe et al. (1977) and Schwarcz et al. (1979), using microspectrofluorometric methods, and Deyo et al. (1979) reported that following a dose of $\beta$-endorphin of the same order of magnitude, the disappearance of dopamine from the striatum after synthesis inhibition with $\alpha$-MPT was increased. Van Loon and Kim (1978) also studied the effects of $\beta$-endorphin on $\alpha$-MPT-induced disappearance of dopamine from rat striatum. In their experiments rats received the tyrosine hydroxylase inhibitor $1 \mathrm{hr}$ prior to the intracisternal injection of either saline or $15 \mu \mathrm{g}$ $\beta$-endorphin, and were decapitated 45 or $90 \mathrm{~min}$ after the last injection. Interestingly, Van Loon and Kim (1978) observed a significantly lower dopamine concentration in the 
striatum of $\beta$-endorphin-treated rats than in that of saline-treated rats 45 min after administration of the peptide, whereas no differences were apparent in the striatal dopamine level of both the groups that were killed $90 \mathrm{~min}$ after the administration of $\beta$-endorphin or saline. This indicated that initially, i.e. in the first $\mathbf{4 5} \mathrm{min}$ after its injection $\beta$-endorphin accelerates, whereas in the second $45 \mathrm{~min}$ period it decreases dopamine utilization. It, therefore, seems possible, also taking into account that the peptide supposedly reaches its sites of action more rapidly following i.c.v. than following intracisternal injection, that, when residual dopamine concentrations are measured shortly after i.c.v. administration (Deyo et al., 1979) or after an i.c.v. infusion (Fuxe et al., 1977; Schwarcz et al., 1979), an increased disappearance is evident, while after longer periods no effects (Izumi et al., 1977), or even opposite effects are seen. Versteeg et al. (1979), using a much lower dose of $100 \mathrm{ng} \beta$-endorphin per rat, i.c.v. found no effect of this peptide on $\alpha$-MPTinduced dopamine disappearance from either the caudate nucleus or the nucleus accumbens; $\alpha$-endorphin $\left(\beta\right.$ - $\left.\mathrm{LPH}_{61-76}\right)$, on the other hand, was found to cause a decrease in dopamine utilization in the caudate nucleus. In these experiments peptides or saline were administered $30 \mathrm{~min}$ after $\alpha$-MPT injection and $3 \mathrm{hr}$ prior to decapitation (Versteeg et al., 1979). It should be noted here that the dose of $100 \mathrm{ng}$ per rat, which is much lower than that which causes analgesia, was chosen on the basis of effects of $\beta$-LPH fragments in extremely low doses on avoidance behavior (De Wied et al., 1978a, b).

Whereas in the above mentioned studies, since the tyrosine hydroxylase inhibitor $\alpha$-MPT was used. effects on dopamine utilization rather than on dopamine synthesis were measured, Garcia-Sevilla et al. (1978; Ahtee et al., 1978; Magnusson et al., 1979), by measuring the accumulation of DOPA following inhibition of DOPA-decarboxylase with NSD 1015, studied the effects of $\beta$-endorphin on striatal catecholamine synthesis. In the experiments in Garcia-Sevilla et al. (1978) the rats received the DOPA-decarboxylase inhibitor $10 \mathrm{~min}$ after i.c.v. saline or $\beta$-endorphin administration and were decapitated 30 min after NSD 1015 injection. Following $\beta$-endorphin, given in a dose of 5 or $10 \mu \mathrm{g}$ per rat i.c.v. significantly more DOPA was found to have accumulated in the striatum than following saline, indicating an enhanced catecholamine synthesis in this brain region; naloxone antagonized this $\beta$-endorphin-induced increase in DOPA accumulation (Garcia-Sevilla et al., 1978).

Effects of $\beta$-endorphin on HVA and/or DOPAC concentrations in rat striatum have been studied by Berney and Hornykiewicz (1977), Van Loon and Kim (1977, 1978) and Guidotti et al. (1979). The former authors reported that $\beta$-endorphin, administered i.c.v. in doses of $1 \mu \mathrm{g}$ and up, caused increases in striatal HVA, which were antagonized by naloxone (Berney and Hornykiewicz 1977). Van Loon and Kim found a significantly increased concentration of both HVA and DOPAC after i.c.v. (Van Loon and Kim. 1977) and intracisternal (Van Loon and Kim 1978) administration of $15 \mu \mathrm{g} \beta$-endorphin. Furthermore. Van Loon and Kim (1978) found that the decrease in striatal HVA and DOPAC concentrations induced by the MAO inhibitor pargyline administered 10 or $40 \mathrm{~min}$ after saline or peptide and $20 \mathrm{~min}$ prior to decapitation, was greater in rats that had received intracisternal $\beta$-endorphin than in rats which had received saline. These findings support the concept that $\beta$-endorphin increases striatal dopamine turnover, at least during the first $60 \mathrm{~min}$ after its administration (Van Loon and Kim, 1978). The $\beta$-endorphin-induced increase in striatal dopamine metabolism appears to be effectuated via opioid receptors: both the increase in striatal HVA and DOPAC levels and the effect on the pargyline-induced decrease in DOPAC level observed in $\beta$-endorphin treated rats were found to be counteracted by naloxone (Van Loon and Kim 1978). In a subsequent paper Van Loon et al. (1978a) reported that the development of tolerance to intracisternal $\beta$-endorphin is associated with a return to normal of dopamine turnover in the striatum. Recently it was shown by Guidotti et al. (1979) that striatal HVA concentrations were increased following intrastriatal injection of $\beta$-endorphin. Taken together, the available data indicate that $\beta$-endorphin is involved in the regulation of striatal dopaminergic activity, possibly via intrastriatal receptors. The effects seem to be doseand time-dependent. 
Like the case for the enkephalins, less is known concerning the effects of endorphins on catecholamine metabolism in other brain regions than the striatum. Izumi et al. (1977) reported a decrease in the $\alpha$-MPT-induced disappearance of dopamine from the midbrain, dissected according to Glowinski and Iversen (1966), following the i.c.v. administration of $50 \mu \mathrm{g} \beta$-endorphin, and a tendency in the same direction in the disappearance of noradrenaline from this same region. Fuxe et al. (1977) and Schwarcz et al. (1979) reported an increased dopamine turnover in the olfactory tubercle, whereas that in the median eminence was found to be decreased. Deyo et al. (1979) also observed a decrease in the turnover of dopamine in the median eminence of rats that had received $15 \mu \mathrm{g}$ $\beta$-endorphin i.c.v. and in the cortex as well. Dopamine turnover in the whole hypothalamus was found to be decreased following intraventricular $(20 \mu \mathrm{g}$; Van Vugt et al., 1979) and intracisternal (15 $\mu \mathrm{g}$; Van Loon et al., 1980) administration of $\beta$-endorphin. Recently, Fuxe et al. (1979a) reported that, whereas a dose of approximately $5 \mu \mathrm{g}$ of $\beta$-endorphin injected i.c.v. only causes a decrease of the dopamine turnover in the medial and the lateral pallisade zones of the median eminence, a dose of approximately $30 \mu \mathrm{g}$ also led to an increase of the turnover of catecholamines in the subependymal layer of the median eminence and in the paraventricular nucleus. These findings, according to Fuxe et al. (1979a), suggest the existence of opioid receptor mechanisms reducing dopamine turnover and increasing that of noradrenaline in the median eminence. Further support for the modulating influence of opioid peptides on tubero-infundibular dopamine activity has been presented by Gudelsky and Porter (1979). These authors showed that the i.c.v. administration of $\beta$-endorphin $(10 \mu \mathrm{g})$ or D-Ala ${ }^{2}$-Met-enkephalimamide $(100 \mu \mathrm{g})$ causes an $85-95^{\circ}$, reduction in the concentration of dopamine in pituitary stalk plasma, an effect which is abolished following naloxone pretreatment.

Garcia-Sevilla et al. (1978) in their study, of which the results concerning the effects on striatal dopamine were mentioned above, also measured the effects of $\beta$-endorphin on the accumulation of DOPA following NSD 1015 in limbic structures, hemispheres, diencephalon and the lower brain stem. These authors reported that the effects were qualitatively similar in all brain regions, but that higher doses (10-20 $\mu$ g. i.c.v.) were needed to double DOPA accumulation in diencephalon and brain stem, than to do that in the other brain regions. Using a dose of $100 \mathrm{ng}$ per rat i.c.v. Versteeg et al. (1979) found that $\beta$-endorphin caused a decrease in the $x$-MPT-induced disappearance of noradrenaline from the ventral part of the nucleus reticularis medullae oblongata, of dopamine in the lateral septal nucleus, and of both amines in the rostral part of the nucleus tractus solitarii; the disappearance of dopamine was increased in the medial septal nucleus and the zona incerta. In this same paper Versteeg et al. (1979) also reported the effects of two other $\beta$-LPH fragments which have been shown to exert a profound influence on avoidance behavior of rats. cf. $\alpha$-endorphin $\left(\beta-\mathrm{LPH}_{61-76}\right)$ and Des-Tyr'-;-endorphin $\left(\beta-\mathrm{LPH}_{62-77}\right) . \alpha$-Endorphin, in a dose range of $0.1-3 \mu \mathrm{g}$ s.c. and $3-100 \mathrm{ng}$ i.c.v. delays the extinction of pole jumping behavior and is more potent in this respect than $\beta$-endorphin (De Wied et al., 1978a). ;-Endorphin and its Des-Tyr ${ }^{1}$ analog both have effects on avoidance behavior opposite to those of $x$-endorphin. i.e. they facilitate the extinction of pole jumping behavior and attenuate passive avoidance behavior (De Wied et al. 1978b). The removal of the N-terminal tyrosine residue of $\vartheta$-endorphin has been found to cause a complete loss of opiate-like activity and to destroy affinity to opioid receptors (for references see De Wied et al., 1978b), and yields a compound which is even more potent than $;$-endorphin on avoidance behavior, significant effects being apparent after doses as low as $30 \mathrm{ng}$ s.c. and $300 \mathrm{pg}$ i.c.v. (De Wied et al., 1978b). It was found (Versteeg et al., 1979) that following the administration of $100 \mathrm{ng}$ i.c.v. the effects of $x$-endorphin on the $x$-MPT-induced disappearance of catecholamines were much more widespread throughout the brain than those of $\beta$-endorphin, and that without exception, when $x$-endorphin affected this parameter, it caused a decrease. The psychopharmacological profile of Des$\mathrm{Tyr}^{1}{ }^{1}$-;-endorphin resembles that of the classic neuroleptics, though it seems to be more specific (De Wied et al., 1978b; Kovács and De Wied 1978: see also De Kloet and De Wied, 1980). Interestingly, Versteeg et al. (1979) found that Des-Tyr ${ }^{1}-\vartheta_{-}$-endorphin 
affected dopamine disappearance from the paraventricular nucleus and the zona incerta in a direction opposite to that induced by $\alpha$-endorphin, and in a direction also seen after the neuroleptic haloperidol. Until now, however, dose-effect data are lacking. The only data concerning a direct comparison of Des-Tyr ${ }^{1}-\gamma$-endorphin and haloperidol show that, whereas $1 \mathrm{hr}$ after the in vivo administration of haloperidol in a dose of $0.62 \mathrm{mg}$ per $\mathrm{kg}$ body weight the in vitro conversion of ${ }^{14} \mathrm{C}$-tyrosine into ${ }^{14} \mathrm{C}$-dopamine by caudate slices was increased, this same dose of Des-Tyr ${ }^{1}-\gamma$-endorphin was ineffective (Weinberger et al., 1979). Similar data have been obtained after the i.c.v. administration of these two compounds by Versteeg, Van Heuven-Nolsen and De Wied (unpublished observations). It might be suggested that the effects of Des- $\mathrm{Tyr}^{1}-\gamma$-endorphin are less general and that the peptide exerts its effects in a way different from that of haloperidol. It could be that, while haloperidol affects brain dopamine systems via an interaction with dopamine receptors, Des-Tyr ${ }^{1}-\gamma$-endorphin interferes with dopamine receptors indirectly, via, as yet unidentified specific receptors localized on a relatively small population of neurons.

\subsection{Interaction with Brain ACETylcholine}

In a series of papers Costa and co-workers have reported the results of their studies of the effects of $\beta$-endorphin on regional acetylcholine turnover in rat brain. $\beta$-Endorphin. given in a dose of approximately $10 \mu \mathrm{g}$ per rat i.c.v., caused a decrease in the turnover of acetylcholine in the hippocampus, nucleus accumbens, globus pallidus and cortex, but. like morphine, not in the caudate nucleus (Moroni et al., 1977a). $x$-Endorphin, in a dose of approximately $20 \mu \mathrm{g}$ had no analgesic activity and did not affect acetylcholine turnover in any of the brain regions studies (Moroni et al., 1977a). It was calculated that the dose of $\beta$-endorphin needed to reduce the acetylcholine turnover in the hippocampus by $50 \%$ is approximately $0.7 \mu \mathrm{g}$ (Moroni et al., 1977a), which makes the peptide several times more potent than morphine (cf. Zsilla et al., 1976). Naltrexone completely prevented both the analgesic action and the effect of $\beta$-endorphin on acetylcholine turnover (Moroni et al., 1977a). In subsequent experiments Moroni et al. (1979b) found that intraseptal administration of approximately $2.5 \mu \mathrm{g}$ of $\beta$-endorphin reduced the turnover of acetylcholine in the hippocampus significantly, but not that in the striatum and cortex. The effect of intraseptal $\beta$-endorphin on hippocampal acetylcholine turnover was prevented by the i.p. administration of naltrexone (Moroni et al., 1978a). On the basis of these data it was concluded that opioid agonists modulate hippocampal acetylcholine turnover via an interaction with opioid receptors in the septum (Moroni et al., 1977b, 1978a). Thus, the activity of acetylcholine-containing neurons projecting from the septum to the hippocampus might be regulated by peptidergic neurons impinging on the cell bodies of the cholinergic neurons in the septum (Moroni et al., 1977b, 1978a).

In contrast to Moroni et al. (1977a), Botticelli and Wurtman (1979) found significant elevations of hippocampal acetylcholine levels following the i.c.v. administration of $10 \mu \mathrm{g}$ $\beta$-endorphin. with peak effects $30 \mathrm{~min}$ after peptide injection. The choline concentration was not changed, while naloxone antagonized the effects of $\beta$-endorphin on acetylcholine levels in the hippocampus (Botticelli and Wurtman, 1979). These authors conclude that their dara are indicating a decreased utilization of acetylcholine in the hippocampus. which is in keeping with the suggestions of Moroni et al. (1978a).

\subsection{InTERACTION WITH BRAIN SEROTONIN}

$\beta$-Endorphin, administered i.c.v. in a dose of $5 \mu \mathrm{g}$ per rat, causes an increase in the NSD 1015-induced accumulation of 5-HTP in limbic regions, striatum, diencephalon and in the lower brain stem, but not in the hemisphere (Garcia-Sevilla et al., 1978; Ahtee et al., 1978; Magnusson et al., 1979). The rise in 5-HTP accumulation, however, takes longer to reach peak values than that of DOPA accumulation (Garcia-Sevilla et al., 1978). Van Loon and De Souza (1978), on basis of changes in the concentrations of 5-HT and 5-HIAA and of differences in the changes in the concentration of 5-HIAA following 
administration of the MAO inhibitor pargyline, concluded that $\beta$-endorphin, given intracisternally in a dose of $15 \mu \mathrm{g}$, causes a decrease in the turnover of 5-HT in the hippocampus and an increase in the brain stem and the hypothalamus. The fact that $\beta$-endorphin caused a decrease in the pargyline-induced accumulation of 5-HT in all three brain regions (Van Loon and De Souza 1978), leaves some doubt concerning the validity of this conclusion.

\subsection{INTERACTION WITH Brain GABA}

Whereas virtually no data are available concerning possible interactions of ACTH-like peptides and enkephalins with brain GABA, a small number of papers have been published showing that $\beta$-endorphin affects GABAergic systems in the brain. Moroni et al. (1978b) reported that $\beta$-endorphin in a dose of approximately $10 \mu \mathrm{g}$, i.c.v., increases the turnover of $\gamma$-aminobutyric acid in the substantia nigra and globus pallidus, while it decreases that in the caudate nucleus. GABA turnover was measured by calculating the relative enrichment in ${ }^{13} \mathrm{C}$ of glutamate and GABA following the infusion of uniformly labeled ${ }^{13} \mathrm{C}$-glucose through the tail vein for $10 \mathrm{~min}$ starting $20 \mathrm{~min}$ after the i.c.v. injection of either saline or $\beta$-endorphin in these brain parts after exposure of the heads of the rats to microwave irradiation (Moroni et al., 1978b). The effects were dose-dependent and could be prevented by naltrexone; no effects were seen on the concentration of either glutamic acid or GABA (Moroni et al., 1978b). Injection directly into the caudatus of approximately $0.7 \mu \mathrm{g} \beta$-endorphin decreased the turnover of GABA in the caudate nucleus, but increased it in the globus pallidus (Moroni et al., 1979). According to these authors it seems likely that activation of opioid receptors located on short GABAcontaining neurons in the caudate nucleus causes the increase of GABA turnover in the globus pallidus, due to a decrease in GABAergic inhibition elicited by short GABA neurons on the long GABA neurons linking the caudate nucleus with the globus pallidus (Moroni et al., 1979). Perez de la Mora et al. (1979) recently reported evidence that $\beta$-endorphin causes an increase in the turnover of GABA in the substantia nigra and the nucleus caudatus. This conclusion was based on the effect of $5 \mu \mathrm{g} \beta$-endorphin, administered i.c.v. on the $\gamma$-vinylGABA-induced accumulation of GABA in these brain structures (Perez de la Mora et al., 1979). The finding of an increased GABA turnover in the caudate nucleus contrasts with the observations of Moroni et al. (1978b, 1979).

\section{CONCLUDING REMARKS}

From the foregoing it will be clear that a considerable number of data has been presented supporting the notion that peptides related to ACTH, MSH and $\beta$-LPH participate in the regulation of the activity of neuronal systems in the brain containing catecholamines, acetylcholine, serotonin and GABA. Notwithstanding the fact that in many cases the obtained results cannot be compared directly because methods, injection schedules, doses, brain dissection, or even all of them are different, and that in some cases, when a comparison is possible, the results are in obvious contradiction, this rather general conclusion seems to be justified. Since the majority of the available data does not go beyond the simple assessment of the presence or absence, as it may be, of effects of peptide $\mathrm{x}$ on parameter $\mathrm{y}$ in brain region $\mathrm{z}$, at present a more detailed characterization of peptide effects on neurotransmitter systems appears to be an exception. Because of this, our present knowledge about where in the brain the interactions take place and about what is the neuronal circuitry involved in the interactions is rather limited. Therefore, it seems worthwhile to consider how, in the planning of future research, advantage can be taken of the experimental designs which led to the acquistion of this knowledge and of the potentials of methods other than those used to measure neurotransmitter metabolism.

For reasons mentioned in the introduction, the efforts up till now have concentrated to a great extent on the interaction of peptides with brain catecholamines or, to be more 
precise, with striatal dopamine. Taken together, due to these efforts, it now is fairly well established that one of the ways in which endorphins modulate striatal dopamine is via an interaction with opioid receptors localized on the terminals of nigro-striatal dopamine neurons (see Sections 3.1. and 4.1.). Similarly, it has been shown that $\beta$-endorphin affects acetylcholine neurotransmission in the septo-hippocampal system following injection into the septum to the same extent as following i.c.v. administration, which suggests that the interaction might be mediated by receptors on the cell bodies of this system rather than on the terminals in the hippocampus (Section 4.2.). Evidently, if such conclusions are to be reached, the experimental design should at least include biochemical measurements following local micro-injection of the peptide in sufficiently small brain regions, as was the case in the two examples given above. Obvious pitfalls in this type of experiments are (a) too large injection volumes, which can easily cause extensive tissue damage and, consequently, leakage of the injected peptide to surrounding brain regions and to the ventricular system, and (b) peptide concentrations which are out of the range of the concentration which can be expected to be reached at the site following i.c.v. administration of the peptide.

From the first example, i.e. that of the interaction of endorphins with striatal dopamine, it is evident that such methods as radioligand binding with appropriate labeled compounds before and after selective lesioning of particular neuronal systems with neurotoxic substances are of great value when data on the location of receptors are to be obtained. There are, however, some complicating factors. In the first place, though the majority of the studied $\beta$-LPH-derivatives is supposed to act via opioid receptors, the available evidence clearly indicates the existence of multiple receptors for this class of substances (for recent reviews see Terenius 1980; Herz et al., 1980). Secondly, there is the observation that some of the $\beta$-LPH-like peptides act via non-opioid receptors (for references see De Kloet and De Wied 1980; Van Nispen and Greven 1980) and that some of the effects of ACTH-like peptides can be blocked by opiate antagonists (see Gispen and Wiegant 1976; Gispen and Isaacson 1980). As far as ACTH-like peptides are concerned, there is, furthermore, the evidence that the putative brain receptors for these peptides seem to be characterized by a very high affinity and a very low capacity, which makes their detection at present impossible (Witter 1980). Nevertheless it seems likely that these approaches will eventually lead to the unraveling of where the interactions of the various peptides with neurotransmitter systems in the brain take place. Obviously. research along these lines cannot do without the guidance of neuroanatomical data concerning the neuronal pathways involved, while it also needs the support of the results of neuropharmacological experiments.

Whereas the present knowledge concerning the neuronal circuitry involved in peptide action is rather limited, apart from some evidence for how the effects of endorphins on striatal dopamine metabolism are brought about, virtually nothing is known concerning the mechanisms of action of the peptides of the ACTH-MSH-endorphin family. In this respect it should be realized that, in addition to effects on neurotransmitter metabolism in the brain, effects of peptides have been described on other neurochemical parameters as well. Those on cyclic nucleotides, phosphoproteins and protein synthesis have been studied most extensively and are the subject of reviews in this series (Wiegant et al., 1980; Dunn 1980). It is not known whether these effects and those discussed here are part of a chain of events triggered by receptor activation and, if so, how these events are associated. The possible mechanisms of action of neuropeptides have been the subject of discussion in a number of reviews in recent years (e.g. Dunn and Gispen 1977; Walter and Hoffman 1977; Gispen et al., 1977; Barchas et al. 1978: Barker 1978; Iversen et al.. 1978; De Wied and Versteeg 1979). It is not the place here to summarize the suggestions put forward in these reviews, which ultimately are all models based on the effects that have been observed of the various peptides and on what is known concerning the mechanisms of action of the classical neuroregulators. Obviously, progress towards a better understanding of how the peptides related to ACTH, MSH and $\beta$-LPH act will depend on the concerted efforts of various neurochemical subdisciplines. 


\section{REFERENCES}

Athee, L., Garcia-Sevilla, J. A., Magnusson, T. and Carlsson, A. (1978) Effects of morphine, naloxone, naltrexone and $\beta$-endorphin on monoamine synthesis in rat brain. In: Characteristics and Function of Opioids, pp. 345-346, VAN REE, J. M. and Terenius, L. (Eds.) Elsevier/North-Holland Biomedical Press, Amsterdam

Algeri, S., Brunello. N.. Caldikini, G. and Consolazione. A. (1978a) Effect of enkephalins on catecholamine metabolism in rat CNS. In: Adrancess in Biochemical Psychopharmacology. Vol. 18: pp. 199-210. COSTA. E. and Trabucchl. M. (Eds.) Raven Press. New York.

Algeri, S. Calderini. G.. Consolazione. A. and Garattini, S. (1977) The effect of methionine-enkephalin and D-alanine-methionine-enkephalinamide on the concentration of dopamine metabolites in rat striatum. Eur. J. Pharmacol. 45: 207-209.

Algeri. S.. Calderini, G., Consolazione. A. and lomuscio. G. (1978b) Interaction of opioid peptides with monoaminergic neurons in the rat CNS. In: Characteristics and Function of Oploids. pp. 347-348, VA: ReF. J. M. and Terknius. L. (Eds.) Elsevier/North-Holland Biomedical Press, Amsterdam.

Algeri. A.. Consolazione, A.. Calderini, G.. Achilli, G.. Puche Canas, E. and Garattini, S. (1978c) Effect of the administration of (D-Ala $\left.{ }^{2}\right)$ methionine-enkephalin on the serotonin metabolism in rat brain. Experientia 34: 1488-1489.

Algeri. S., Consolazione. A., Calderini, G. and Lomuscio, P. (1979) Enkephalin interaction with dopaminergic systems in rat CNS. In: Catecholamines: Basic and Clinical Frontiers, pp. 1092-1094. Usdin, E., KopIN. I. J. and Barchas. J. (Eds.) Pergamon Press. New York.

ARbiLla. S. and LANGer, S. Z. (197x) Morphine and $\beta$-endorphin inhibit release of noradrenaline from cerebral cortex but not of dopamine from rat striatum. Nature 271: 559-561.

Barchis. J. D., Akil. H.. Elliott. G. R. Holman, R. B. and Watson, S. J. (1978) Behavioral neurochemistry: neuroregulators and behavioral states. Science 200: 964-973.

Barker: J. L. (1978) Evidence for diverse cellular roles of peptides in neuronal function, Neurosciences Res. Progr. Bull. 16: 535555

Barker. J. L. and SMiTh. T. G. (1979) Three modes of communication in the nervous system. Adt. Exp. Med. Biol. $116: 3,25$.

Bellet, M.. Elghozi. J. L. and Mrijek. P. (1979) The centrally mediated cardiovascular effect of opioids. In: Brain Peptides: Vew Endocrinol. Proc. Argentueil Simp., 4th. 1978. pp. 365-371, GotTo, A. M. PeCk. J. and BoyD, A. E. (Eds.) Elsevier, Amsterdam

BERNEY. S. and HoRNYKIEwicz. O. (1977) The effect of $\beta$-endorphin and met-enkephalin on striatal dopamine metabolism and catalepsy: comparison with morphine. Commun. Psychopharmacol. 1 : 597-604.

Biggio. G.. Cast: M.. Coriba. M. G.. Di Bello, C. a.d Gessa. G. L. (1978a) Stimulation of dopamine synthesis in caudate nucleus by intrastriatal enkephalins and antagonism by naloxone. Science 200: 552-554

Biggio. G.. Cokida. M. G.. CAst. M. and GisSa. G. L. (1978b) Striato-cerebellar pathway controlling cyclic GMP content in the cerebcllum: role of dopamine. GABA and enkephalins. In: Adr. Biochem. Psychophurmacol. Vol. 18: pp. 227 244. Costa. E. and Trabl cchi. M. (Eds.) Raven Press. New York.

Bläsig, J., Höllt, V., BaEuerLe. U. and Herz. A. (1978) Involvement of endorphins in emotional hyperthermia of rats. Life Sci. 23: 2525-2531.

Bloom. F. Segal. D. LiNG. N. and GLillimis. R. $(1976)$ Endorphins profound behavioral effects in rat. suggest new etiological factors in mental illness. Science 194: 630-631.

BoHLS. B. (1980) Effect of LPH. ACTH and MSH on adaptive behaviour. In: Polypeptides. Me'mory and Behariour: Phamacology and Therapeanics. Pergamon Press. Oxford (in press).

Bolme. P.. Fixe. K.. Agiati. L. F. Bradli. R. and Smithifs. J. (1978) Cardiovascular effects of morphine and opioid peptides following intracisternal administration in chloralose-anesthetized rats. Eur. J. Pharmacol. $48: 319324$.

BotTICELLI. L. J. and WLRTMAN. R. J. (1979) $\beta$-Endorphin administration increases hippocampal acetylcholine levels. Life Sci. 24: 1799-1804.

Braibil Ry. A. F.. Filidberg. W. F. SMYth. D. G. and Svitl. C. (1976) Lipotropin C-fragment: an endogenou: peptide with potent analgesic activity. In: Opiates and Endogenons Opioid Peptides. pp. 9-17. Kostralitz H. W. (Ed.). Elsevier North-Holland. Amsterdam.

BRASE. D. A. (1979) Roles of serotonin and "-aminobutyric acid in opiod effects. In: Neurochemical Mechamism. of Opiates and Endorphins. Adt. Biochem. Psychopharmacol. Vol. 20: pp. 409-428.

Calditivi. G. Cossolazioni. A. Sarattivi. S. and Algeki. S. (1978) Different effects of methionine-enkephalin and (D-Ala ${ }^{2}$ )methionine- nnkephalinamide on the metabolism of dopamine and norepinephrine in rat brain: fact or artifact? Brain Re's. 146:392-399.

Cariazi. A.. Frighis. V. and Dilla Billa. D. (1978) S!naptic localization of opiate receptors in rat striatum. Adr. Biochem. Psichopharmacol. Vol. 18. Costa. E. and Trablcchi. M. (Eds.) Raven Press. New York.

Clark. W. G. (1979) Influence of opioids on central thermoregulatory mechanisms. Pharmacol. Biochem. Behat: 10: $609-613$

Cools. A. R.. Witgayt. V. M. and Gispr., W. H. (1978) Distinct dopaminergic systems in ACTH-induced grooming. Eur. J. Pharmacol. 50: 265268 .

Di: CARO. G.. MICRoSsI. L. G. and VINTLRI. F. (1979) Drinking Behavior induced by intracerebroventricular administration of enkephalins to rats. Narure $277: 5153$.

De KLol: T. E. R. and DE WIt:D. D. (1980) The brain as target tissue for hormones of pituitary origin: behavioral and biochenical studies. In: Frontiers in Tinoendocrinology. Vol. 6. pp. 157-201. Martivi. L. and Gavovg. W. F. (Eds.) Raven Press. New York.

Di Klol:t. E. R. Mezry. E. and Palkovits. M. (1980) The localization. source and avenues of transport of opiocortins. In: Polypeptides. Memory and Behatiour: Pharmacoloy! and Therapeatics. Pergamon Press. Oxford (in press).

DI: W(E1). D. (1966) Inhibitory effect of ACTH and related peptides on extinction of conditioned avoidance behavior of rats. Proc. Soc: Exp. Biol. Med. $122: 28$. 32 . 
DE WIED, D. (1969) Effects of peptide hormones on behavior. In: Frontiers in Neuroendocrinology; pp. 97-140, Ganong, W. F. and Martini, L. (Eds.), Oxford University Press, New York.

DE WIED. D. and Versteeg. D. H. G. (1979) Neurohypophyseal principles and memory, Fed. Proc. 38: $2348-2354$

De Wied, D., Bohus, B., Van Ree, J. M. and Urban, J. (1978a) Behavioral and electrophysiological effects of peptides related to lipotropin ( $\beta$-LPH). J. Pharmacol. Exp. Ther. 204: 570-580.

De Wied, D.. Kovács, G. L., Bohus, B.. Van Ree, J. M. and Greven, H. M. (1978b) Neuroleptic activity of the neuropeptide $\beta-\mathrm{LPH}_{62-77}$ ([Des-Tyr $\left.{ }^{1}\right] \gamma$-endorphin; DT;E), Eur. J. Pharmacol. 49: 427-436.

De Wied, D., Van Delft, A. M., Gispen, W. H., Weynen, J. A. W. M. and Van Wimersma Greidanus, T. B. (1972) The role of pituitary-adrenal system hormones in active avoidance conditioning. In: Hormones and Behatior, pp. 135-171, Levine, S. (Ed.). Academic Press. New York.

Deyo. S. N.. SwifT, R. M. and Miller, R. J. (1979) Morphine and endorphins modulate dopamine turnover in rat median eminence. Proc. Natn. Acad. Sci. USA 76: 3006-3009.

Domino. E. F. (1979) Opiate interactions with cholinergic neurons, In: Neurochemical Mechanisms of Opiates and Endorphins, Adr. Biochem. Psychopharmacol. Vol. 20, pp. 339-356.

Dunn, A. J. (1980) Neuropeptides and brain protein synthesis, In: Polypeptides. Memory and Behaciour: Pharmacology and Therapeutics, Pergamon Press. Oxford, (in press).

Dunn. A. J. and GisPen, W. H. (1977) How ACTH acts on the brain. Behav. Rev. 1: 15-23.

Dunn, A. J., Gildersleeve, N. B. and Gray, H. E. (1978) Mouse brain tyrosine hydroxylase and glutamic acid decarboxylase following treatment with adrenocorticotrophic hormone, vasopressin of corticosterone. $J$. Neurochem. 31 : 977-982.

Dunn, A. J., Iuvone, P. M. and ReEs, H. D. (1976) Neurochemical responses of mice to ACTH and lysine vasopressin. Pharmacol. Biochem. Behar. 5, Suppl. 1: 139-145.

Dupont, A., Cusan, L., Ferland, L., Lemay, A. and Labrie, F. (1979) Evidence for a role of endorphins in the control of prolactin secretion, In: Central Nervous System Effects of Hypothalamic Hormones and Other Peptides, pp. 283-300, Collu, R., Barbeal. A., Ducharme, J. R. and Rochefort, J. G. (Eds.) Raven Press. New York.

ENDRÖczı, E. (1976) Effect of $\mathrm{ACTH}_{1-24}$ and $\mathrm{ACTH}_{4-10}$ on distribution of ${ }^{3} \mathrm{H}$-noradrenaline in the brain of adrenalectomized rats. Acta Physiol. Acad. Sci. Hung. 48: 59-64.

ENDRÖczI, E. (1977) Brain mechanisms involved in ACTH-induced changes of exploratory activity and conditioned avoidance behavior. In: Neuropeptide Influences on the Brain and Behavior, pp. 179-187, MiLLER, L. H., Sandman, C. A. and Kastin, A. J. (Eds.), Raven Press, New York.

Endröczi, E., Hraschek, A., Nyakas, Cs. and Szabo. G. (1975) Brain catecholamines and pituitary-adrenal function, In: Cellular and Molecular Base of Neuroendocrine Processes, pp. 607-618. ENDöczI. E. (Ed.) Akademial Kiado, Budapest.

Fekete, M., Herman, J. P.. Stark. E. and Palkovits, M. (1976) ACTH induced changes in the transmitter amine concentration of individual brain nuclei of the rat In: Catecholamines and Stress, pp. 69-75. UsDiN. E. (Ed.) Pergamon Press, Oxford.

Fekete, M. I., Stark, E., Herman, J. P., Palkovits, M. and Kanyicska, B. (1978) Catecholamine concentration of various brain nuclei of the rat as affected by ACTH and corticosterone. Neurosci. Letters 10: 153-158.

Ferland, L.. Fuxe, K., Eneroth, P., Gustafsson, J.-A. and Skett, P. (1977) Effects of methionine-enkephalin on prolactin release and catecholamine levels and turnover in the median aminence. Eur. J. Pharmacol. 43 89-90.

Ferrari, W. Gessa. G. L. and Vargiu, L. (1963) Behavioral effects induced by intracisternally injected ACTH and MSH. Amn. N.Y. Acad. Sci. 104: 330-345.

Fuxe, K., Andersson, K., Hökfelt, T., Mutt, V., Ferland, L., Agnati, L. F., Ganten, D., Said, S., Eneroth, P. and Gustafsson, J.-A. (1979a) Localization and possible function of peptidergic neurons and their interactions with central catecholamine neurons, and the control action of gut hormones, Fed. Proc. 38 $2333-2340$.

Fuxe, K., Bolme, P., Jonsson, G., Agnati, L. F., Goldstein, M., Hökfelt, T., Schwarz, R. and Engel, J. (1979b) On the cardiovascular role of norepinephrine, adrenaline and peptide containing neuro systems in the brain, In: Nervous System and Hypertension, pp. 1-17. Meyer. P. and SchmitT, H. (Eds.) Wiley Flammarion, Paris

Fuxk. K.. Corrodi, H., Hökfelt, T. and Jonsson, G. (1970) Central monoamine neurons and pituitary-adrenal activity. In: Pituitary, Adrenal and the Brain, DE WIED, D. and Weynen, J. A. W. M. (Eds.), Progr. Brain Res. Vol. 32: Elsevier, Amsterdam

Fuxe, K., Ferland, L.. Agnati, L. F., Eneroth, P., Gustafsson. J.-A., Labrie, F. and Skett, P. (1977) Effects of intraventricular injections of $\beta$-endorphin on dopamine levels and turnover in the unanesthetized male rat. Evidence for an increase of dopamine turnover in the caudatus and in the limbic forebrain and for a decrease of dopamine turnover in the median eminence. Acta Pharmacol. Toxicol. 41, Suppl. IV, p. 48.

Garcia-Sevilla, J. A.. Ahtee. L.. Magnusson, T. and Carlsson, A. (1978) Opiate-receptor mediated changes in monoamine synthesis in rat brain. J. Pharm. Pharmac. 30: 613-621.

Garcia-Sevilla, J. A., Magnusson. T, and Carlsson. A. (1980) Effects of enkephalins and two enzyme resistant analogues on monoamine synthesis and metabolism in rat brain, Naunyn-Schmiedeberg's Arch. Pharmacol. 310: 211-218.

Gispen, W. H. and IsaAcSON, R. (1980) Peptide-induced stereotypies (SYS and excessive grooming). In: Polypeptides, Memory and Behaviour: Pharmacology and Therapeutics, Pergamon Press, Oxford, (in press).

GisPEN, W. H. and WIFGANT, V. M. (1976) Opiate antagonists suppress ACTH ${ }_{1-24}$-induced excessive grooming in the rat, Neurosci. Letters 2: 159-164.

Gispen, W. H., Reith, M. E. A., Schotman, P., Wiegant, V. M., Zwiers, H. and De Wied, D. (1977) The CNS and ACTH-like peptides: neurochemical response and interaction with opiates, In: Neuropeptides Influences on the Brain and Behatior, pp. 61-80. Miller, L. H., Sandman, C. A. and Kastin, A. J. (Eds.) Raven Press. New York. 
Gispen, W. H., Wiegant, V. M., Bradbury, A. F. Hulme, E. C., Smyth, D. G., Snell, C. R. and Di. Wied, D. (1976) Induction of excessive grooming in the rat by fragments of lipotropin, Nature 264: 794-795.

GlowiNSKI. J. and IVERSEN, L. L. (1966) Regional studies of catecholamines in the rat brain. I. The disposition of $\left[{ }^{3} \mathrm{H}\right]$ norpinephrine. $\left[{ }^{3} \mathrm{H}\right]$ dopamine and $\left[{ }^{3} \mathrm{H}\right]$ DOPA in various regions of the brain. $J$. Neurochem. 13: $655-669$.

Göthert, M., Pohl, I. M. and Wfhking, E. (1979) Effects of presynaptic modulators of calcium $(2+$ lioninduced noradrenaline release from central noradrenergic neurons. Noradrenaline and enkephalin inhibit release by decreasing depolarization-induced calcium $(2+)$ ion influx. Naunyn Schmiedebergs' Arch. Pharmacol. 307: 21-27.

GrandisON, L. and GuidotTi, A. (1977) Stimulation of food intake by muscimol and $\beta$-endorphin. Neuropharmacology 16: 533-536.

Guidotti, A. Moroni, F.. Gale, K. and Kumakura, K. (1979) Opiate receptor stimulation blocks the activation of striatal tyrosine hydroxylase $(\mathrm{TH})$ induced by haloperidol, In: Catecholamines: Basic and Clinical Frontiers, pp. 1035-1037, Usdin, E., Kopin, I. J. and Barchas, J. (Eds.) Pergamon Press, New York.

Gudelsky, G. A. and Porter, J. C. (1979) Morphine- and opioid peptide-induced inhibition of the release of dopamine from tuberoinfundibular neurons, Life Sci. 25: 1697-1702.

Hambrook, J. M., Morgan, B. A., Rance, M. J. and Smith, C. F. O. (1976) Mode of deactivation of the enkephalins by rat and human plasma and rat brain homogenates. Nature 262: 782-783.

HarSiNG, L. G.. VIZI, E. S. and KNOLL, J. (1978) Increase by enkephalin of acetylcholine release from striatal slices of the rat. Pol. J. Pharmacol. Pharm. 30: 387-395.

Herz, A., SChulz, R. and Wüster, M. (1980) Some aspects of opiate receptors. In: Receptors for Neurotransmitters and Peptide Hormones, pp. 329-337. Pepeu, G., Kuhar, M. J. and EnNA, S. J. (Eds.) Raven Press, New York.

HÖKFELT, T. and FUXE. K. (1972) On the morphology and the neuroendocrine role of the hypothalamic catecholamine neurons. In: Brain-Endocrine Interaction. Median Eminence: Structure and Function, pp. 181-223, KNigge, K. M., Scott, D. E. and Weinde, A. (Eds.) Int. Symp. held in München, 1971. Karger. Basel.

Hökfelt, T., Johanson, O., Luungdahl, ^., Lundberg, J. M. and Schultzberg, M. (1980) Peptidergic neurons, Nature 284: 515-521.

HoladAy, J. W. and LOH, H. H. (1979) Endorphin-opiate interactions with neuroendocrine systems, In: Neurochemical Mechanisms of Opiates and Endorphins, Adv. Biochem. Psychopharmacol.. Vol. 20, pp. 227-258. LoH, H. H. and Ross, D. H. (Eds.) Raven Press, New York.

Holaday. J. W., Wei, E., Loh, H. H. and Li. C. H. (1978) Endorphins may function in heat adaptation, Proc. Natn. Acad. Sci. U.S.A. 75: 2923-2927.

HUGHES, J. (1975) Isolation of an endogenous compound from the brain with pharmacological properties similar to morphine. Brain Res. 88: 295-308.

Hughes. J., Smith, T. W., Kosterlitz. H. W., Fothergill, L. A., Morgan, B. A. and Morris, H. R. (1975) Identification of two related pentapeptides from the brain with potent opiate agonist activity. Nature 258: $577-579$.

Iuvone. P. M.. Morasco, J.. Delanoy, R. L. and Dunn, A. J. (1978) Peptides and the conversion of $\left({ }^{3} \mathrm{H}\right)$ tyrosine to catecholamines: effects of ACTH-analogs, melanocyte-stimulating hormones and lysine-vasopressin. Brain Res. 139: 131-139.

Iversen, L. L., Nicoll, R. A. and Vale, W. W. (1978) Neurobiology of peptides, Neurosciences Res. Progr. Bull. 16: $211-370$

Iwamoto, E. T. and WAy, E. L. (1979) Opiate actions and catecholamines. In: Neurochemical Mechanisms of Opiates and Endorphins, Adv. Biochem. Psychopharmacol. Vol. 20, pp. 357-407.

Izumi, K., Motomatsu, T, and Chrétien, M. (1977) $\beta$-Endorphin induced akinesia in rats: Effects of apomorphine and $x$-methyl-p-tyrosine and related modifications of dopamine turnover in the basal ganglia. Life Sci. 20: $1149-1156$.

Javoy, F., GLowinSKi, J. and KORDON, C. (1968) Effects of adrenalectomy on the turnover of norepinephrine in the rat brain. Eur. J. Pharmacol. 4: 103-104.

J HAMANDAS, K., SAWYNOK, J. and SutAK, M. (1977) Enkephalin effects on release of brain acetylcholine. Nature 269: $433-434$.

King, M. G., Kastin, A. J., Olson, R. D. and Coy, D. H. (1979) Systemic administration of Met-enkephalin. (D-Ala $\left.{ }^{2}\right)$-Met-enkephalin, $\beta$-endorphin and (D-Ala ${ }^{2}$ - $\beta$-endorphin: effects on eating, drinking and activity measurements in rats. Pharmacol. Biochem. Behav. 11: 407-411.

Kostrzewa, R. M. Kastin, A. J. and SPIRTES, M. A. (1975) $x$-MSH and MIF-I effects on catecholamine levels and synthesis in various rat brain areas. Pharmacol. Biochem. Behav. 3: 1017-1023.

Kovács, G. L. and DE WIED, D. (1978) Effects of amphetamine and haloperidol on avoidance behavior and exploratory activity. Eur. J. Pharmacol. 53: 103-197.

LASKA, F. J. and FENNESSY, M. R. (1978) Modification of brain biogenic amines by Met ${ }^{5}$-enkephalin amide in the rat. Clin. Exp. Pharmacol. Physiol. 5: 95-98.

Laubie, M., Schmitt, H., VinCENt, M. and Remond, G. (1977) Central cardiovascular effects of morphinomimetic peptides in dogs. Eur. J. Pharmacol 46: 67-71.

Lemaire, I., Tseng, R. and Lemaire, S. (1978) Systemic administration of $\beta$-endorphin: potent hypotensive effect involving a serotonergic pathway. Proc. Natn. Acad. Sci. U.S.A. 75: 6240-6242.

LEONARD. B. E. (1974) The effects of two synthetic ACTH analogues on the metabolism of biogenic amines in the rat brain. Arch. Int. Pharmacodyn. Thér. 207: 242-253.

Leonard, B. E., Kafoe, W. F., Thody, A. J. and Shuster, S. (1976) The effects of $\alpha$-melanocyte stimulating hormone $(\alpha-\mathrm{MSH})$ on the metabolism of biogenic amines in the rat brain. J. Neurosci. Res, $2: 39-45$.

Li, C. H. and Chung, D. (1976) Isolation and structure of an untriakontapeptide with opiate activity from camel pituitary gland. Proc. Natn. Acad. Sci. 73: 1145-1148. 
LiChtensteIGer, W. and LiEnhart, R. (1977) Response of mesencephalic and hypothalamic dopamine neurones to $\alpha$-MSH: mediated by area postrema. Nature $266: 635-637$.

Lichtensteiger, W. and MonNet, F. (1979) Differential response of dopamine neurons to $x$-melanotropin and analogues in relation to their endocrine and behavioral potency. Life Sci. 25: 2079-2087.

Lichtensteiger, W., Felix, D., Lienhart, R. and Hefti, F. (1976) A quantitative correlation between single unit activity and fluorescence intensity of dopamine neurones in zona compacta of substantia nigra, as demonstrated under the influence of nicotine and physostigmine, Brain Res. 117: 85-103.

Lichtensteiger, W., Monnet, F. and Felix. D. (1979) Peptide effects on mammalian and invertebrate dopamine (DA) neurons. In: Catecholamines: Basic and Clinical Frontiers, pp. 1086-1088, UsDIN, E., Kopin, I. J. and Barchas, J. (Eds.) Pergamon Press, New York.

LIN, M. T., Cheris, Y. F., CHEN, F. F. and SU, C. Y. (1979) Serotoninergic mechanisms of $\beta$-endorphin-induced hypothermia in rats. Pfiügers Arch. 382: 87-90.

Loh. H. H., Brase, D. A., Sampath-Khanna, S. Mar, J. B., Way, E. L. and Li, C. H. (1976) $\beta$-Endorphin in vitro inhibitation of striatal dopamine release. Nature 264: 567-568.

Magnusson, T., Garcia-Sevilla, J. A. and Carlsson, A. (1979) Effects of peptides on brain monoamine metabolism and on gross behaviour in rats, In: Catecholamines: Basic and Clinical Frontiers, pp. 1209-1211, Usdin, E., Kopin, I. J. and Barchas, J. (Eds.) Pergamon Press, New York.

Margules, D. L., Moisset, B., Lewis, M. J., Shibuya, H. and Pert, C. B. (1978) $\beta$-Endorphin is associated with overeating in genetically obese mice (ob/ob) and rats (fa/fa). Science 202: 988-991.

Meites, J., Bruni, J. F. and VAN Vugt, D. A. (1979) Effects of endogenous opiate peptides on release of anterior pituitary hormones, In: Central Nervous System Effects of Hypothalamic Hormones and Other Peptides, pp. 261-271, Collu, R., Barbeau, A., Ducharme, J. R. and Rochefort, J. G. (Eds.) Raven Press, New York.

Miller, R. J. (1980) Peptides as neurotransmitters: focus on the enkephalins and endorphins, In: Polypeptides. Memory and Behaviour; Pharmacology and Therapeutics, Pergamon Press, Oxford, (in press).

Moroni, F., Cheney, D. L. and COSTA, E. (1977a) $\beta$-Endorphin inhibits ACh turnover in nuclei of rat brain. Nature 267: 267-277.

Moroni, F., ChEney, D. L. and Costa, E. (1977b) Inhibition of acetylcholine turnover in rat hippocampus by intraseptal injection of $\beta$-endorphin and morphine. Naunyn-Schmiedebergs Arch. Pharmacol. 299: 149-153.

Moroni, F. Cheney, D. L. and Costa, E. (1978a) The turnover rate of acetylcholine in brain nuclei of rats injected intraventricularly and intraseptally with alpha and beta-endorphin. Neuropharmacology 17: 191-196.

Moroni, F., Cheney, D. L., Peralta, E. and Costa, E. (1978b) Opiate agonists as modulators of $\gamma$-aminobutyric acid turnover in the nucleus caudatus, globus pallidus and substantia nigra of the rat. $J$. Pharmacol. Exp. Ther. 207: 870-877.

Moroni, F.. Peralta, E., Cheney, D. L. and Costa, E. (1979) On the regulation of $\gamma$-aminobutyric acid neurons in caudatus, pallidus and nigra: effects of opioids and dopamine agonists. J. Pharmacol. Exp. Ther. 208: 190-194.

MeEK, J. L., YANG, H.-Y. and COSTA, E. (1977) Enkephalin catabolism in vitro and in vivo. Neuropharmacology 16: $151-154$.

Palkovits. M. (1973) Isolated removal of hypothalamic or other nuclei of the rat. Brain Res. 59: 449-450.

Perez de la Mora, M., Fuxe, K., Andersson, K., Hökfelt, T., Ljundahl, Å., Possani, L. and Tapia, R. (1979) Studies on GABA-monoamine and GABA-endorphin interactions. In: Catecholamines: Basic and Clinical Frontiers, pp. 1032-1034, Usdin, E., Kopin, I. J. and Barchas, J. (Eds.) Pergamon Press, New York.

Pollard, H., Llorens-Cortes, C. and Schwartz, J. C. (1977) Enkephalin receptors on dopaminergic neuronses in rat striatum. Nature $268: 745-747$.

Pollard, H., Llorens, C., Schwartz, J. C., Gros, C. and Dray, F. (1978) Localization of opiate receptors and enkephalins in the rat striatum in relationship with the nigrostriatal dopaminergic system: lesion studies. Brain Res. 151: 392-398.

Ramaekers, F., Rigter, H. and LeOnard, B. E. (1978) Parallel changes in behaviour and hippocampal monoamine metabolism in rats after administration of ACTH-analogues. Pharmacol. Biochem. Behat. 8 $547-551$.

Schwarcz, R., Fuxe, K., Andersson, K. and Ferland, L. (1979) $\beta$-Endorphin and met-enkephalin induced changes in amine turnover in discrete DA nerve terminal systems of the neostriatum and the limbic forebrain. In: Catecholamines: Basic and Clinical Frontiers, pp. 1047-1049, UsDin, E., Kopin, I. J. and Barchas, J. (Eds. Pergamon Press, New York.

Schwartz, K. C., De la Baume, S., Llorens, C., Patey, G. and Pollard, H. (1979) Opiate receptors localized presynaptically on dopaminergic and noradrenergic neurons in brain: relevance to tolerance and dependence to opioids, In: Catecholamines: Basic and Clinical Frontiers, pp. 1083-1085, Usdin, E., Kopin, I. J. and Barchas, J. (Eds.) Pergamon Press, New York.

Schwartz, J. C., Pollard, H., llorens, C., Malfroy, B., Gros, C., Pradeles, Ph. and Dray, F. (1978) Endorphins and endorphin receptors in striatum: relationship with dopaminergic neurons. In: Advances in Biochemical Psychopharmacoloty, Vol. 18, pp. 245-264, Costa, E. and TrabuCCHI, M. (Eds.), Raven Press, New York.

Scoto, G. M., Spadaro, C., Spampinato, S., Arrigo-Reina, R. and Ferri, G. (1979) Prostaglandins in the brain of rats given acutely and chronically, a hyperthermic dose of met-enkephalin. Psychopharmacology 60 : $217-219$.

Simantov, R. and SNyder. S. H. (1976) Isolation and structure identification of a morphine-like peptide 'enkephalin' in bovine brain. Life Sci. 18: 781-788.

Simon, W., Schaz, K., Gunter, U., Stock, G., Schloer, K. H. and Ganten, D. (1978) Effects of enkephalins on arterial blood pressure are reduced by propranolol. Clin. Sci. Mol. Med. 55. Suppl. 4, 237S-241S.

Spirtes, M. A., Kostrzewa, R. M. and KASTIN, A. J. (1975) $x$-MSH and MIF-I effects on serotonin levels and accumulation in various rat brain areas. Pharmacol. Biochem. Behat. 3: 1011-1015. 
Subramanian, N., Mitznegg, P., Sprügel, W., Domschke, S., Wünsch, E. and Demling, L. (1977) Influences of enkephalin on $\mathrm{K}^{+}$-evoked efflux of putative neutotransmitters in rat brain. Naunyn-Schmiedeberg's Arch. Pharmacol. 299: 163-165.

Taché, Y. Charpenet, G., Chrétien, M. and Collu, R. (1979) Role of serotonergic pathways in hormonal changes induced by opioid peptides. In: Central Nervous System Effects of Hypothalamic Hormones and Other Peptides, pp. 301-313, Collu, R., Barbeau, A., Ducharme, J. R. and RocheforT, J. G. (Eds.) Raven Press, New York.

Taube, H. D., Borowski, E., Endo. T. and Starke, K. (1976) Enkephalin: a potential modulator of noradrenaline release in rat brain. Eur. J. Pharmacol. 38: 377-380.

TEleGdy. G. and Kovács, G. L. (1979a) Role of monoamines in mediating the action of ACTH, vasopressin and oxytocin. In: Central Nertous System Effects of Hypothalamic Hormones and Other Peptides. pp. 189-205, Colle, R., Barbeau, A., Ducharme J. R. and Rochefort, J. G. (Eds.) Raven Press, New York.

Telegdy, G. and Kovács, G. L. (1979) Role of monoamines in mediating the action of hormones on learning and memory. In: Brain Mechanisms in Memory and Learning: From single neuron to Man. pp. 249-268. Brazier, M. A. B. (Ed.) IBRO Monograph Series, Raven Press, New York.

TERENIUS, L. (1980) Opiate receptors: problems of definition and characterization, In: Receptors for Neurotransmitters and Peptide Hormones, pp. 321-328, Pepeu, G., Kuhar, M. J. and Enna, S. J. (Eds.) Raven Press, New York

Teschemacher, H., Opheim, K. E.. Cox, B. M. and Goldstein, A. (1975) A peptide-like substance from pituitary that acts like morphine. I Isolation. Life Sci. 16: 1771-1776.

Trabucchi, M., Polo, A. Tonon, G. C. and Spano, P. F. (1979) Interaction among enkephalinergic and dopaminergic systems in striatum and limbic forebrain. In: Catecholamines: Basic and Clinical Frontiers, pp. 1053-1055, Usdin, E.. Kopin, I. J. and Barchas, J. (Eds.) Pergamon Press, New York.

VAN LOON, G. R. (1973) Brain catecholamines and ACTH secretion. In: Frontiers in Neuroendocrinology, pp. 209-247. Martini, L. and Ganong, W. F. (Eds.), Oxford University Press, New York.

VAn Loon. G. R. and De Souza. E. B. (1978) Effects of $\beta$-endorphin on brain serotonin metabolism. Life Sci. 23: $971-978$.

VAN LOON. G. R. and KIM, C. (1977) Effect of $\beta$-endorphin on striatal dopamine metabolism. Res. Commun. Chem. Pathol. Pharmacol. 21 : $171-174$.

VAN LOON, G. R. and KIM. C. (1978) $\beta$-Endorphin-induced increase in striatal dopamine turnover. Life Sci. 23 $961-970$.

VAn Loon, G. R., De Souza, E. B. and KIM, C. (1978a) Alterations in brain dopamine and serotonin metabolism during the development of tolerance to human $\beta$-endorphin in rats. Can. J. Physiol. Pharmacol. 56 $1067-1071$

VAN LOON, G. R., Ho, D. and KIM, C. (1980) $\beta$-Endorphin-induced decrease in hypothalamic dopamine turnover, Endocrinology 106: 76-80.

Van Loon, G. R. Sole, M. J., Kamble, A. Kim. C. and Green, S. (1978b) Differential responsiveness of central noradrenergic and dopaminergic neuron tyrosine hydroxylase to hypophysectomy, ACTH, and glucocorticoid administration. Ann. N.Y. Acad. Sci. 297: 284-293.

VAN NisPen, J. and Greven, H. M. (1980) Structure-activity studies on LPH. ACTH and MSH on behaviour. In: Polypeptides-Memory and Behaviour: Pharmacology and Therapeutics, Pergamon Press. Oxford. (in press).

Van Vugt, D. A., Bruni, J. F.. Sylvester, P. W., Chen, H. T., Ieiri, T. and Meites, J. (1979) Interaction between opiates and hypothalamic dopamine on prolactin release, Life Sci. 24: 2361-2367.

VFrsteEg. D. H. G. (1973) Effect of two ACTH-analogs on noradrenaline metabolism in rat brain. Brain Res 49. $483-485$

VersteEG, D. H. G. and WurTman, R. J. (1975) Effect of ACTH ${ }_{4-10}$ on the rate of synthesis of $\left[{ }^{3} \mathrm{H}\right]$ catecholamines in the brains of intact, hypophysectomized and adrenalectomized rats. Brain Res. 93: $552-557$.

Versteeg, D. H. G., De KLOET, E. R. and DE Wied, D. (1978) Interaction of endorphins with brain catecholamine systems. In: Characteristics and Function of Opioids, pp. 323-VAN REE, J. M. and TerenIUS, L. (Eds.). Elsevier/North-Holland Biomedical Press. Amsterdam.

Versteeg, D. H. G.. DF Kloet, E. R. and De Wied, D. (1979) Effects of $x$-endorphin, $\beta$-endorphin and (Des-Tyr)-;-endorphin on $x$-MPT-induced catecholamines disappearance in discrete regions of the rat brain. Brain. 179: 85-92.

Virstel:G. D. H. G. Gispen, W. H. Schotman, P. WitTer, A. and De Wied. D. (1972) Hypophysectomy and rat brain metabolism: effects of synthetic ACTH analogs. Adv. Biochem. Psychopharmacol. 6: 219-239.

VIZI. E. S., Harsing. L. G. and KNOLL, J. (1977) Presynaptic inhibition leading to disinhibition of acetylcholine release from interneurons of the caudate nucleus: effect of dopamine, $\beta$-endorphin and D-Ala ${ }^{2}-$ Pro $^{5}$ enkephalinamide. Neuroscience 2: 953-961.

Walter, R. and Hoffman, P. L. (1977) Proposed mechanisms of action of neurohypophyseal peptides in memory processes and possible routes for the biosynthesis of peptides with a C-terminal carboxamide group, In: Neuropeptides Influences on the Brain and Behavior, pp. 109-126, Miller, L. H., SANDMAN. C. A. and Kastin, A. J. (Eds.) Raven Press. New York.

Weinberger, S. B., Arnsten, A. and Segal, D. S. (1979) Des-Tyrosine ${ }^{1}-\hat{\imath}$-endorphin and haloperidol: behavioral and biochemical differentiation. Life Sci. 24: 1637-1644.

Weiss, J. M. McEwen, B. S. Silva, M. T. and KalkLt, M. (1970) Pituitary-adrenal alterations and fear responding. Am. J. Physiol. 218: $864-868$

WIEGANT. V. M.. COOLS, A. R. and GISPEN, W. H. (1977) ACTH-induced grooming involves brain dopamine. Eur. J. Pharmacol. $41: 343-345$.

WIEGANT, V. M., ZWIERS, H. and GiSPI:N. W. H. (1980) Neuropeptides and brain cAMP and phosphoproteins, In: Polypeptides, Memory and Behaciour: Pharmacology and Therapeutics. Pergamon Press, Oxford (in press). 
WITTER. A. (1980) On the presence of receptors for ACTH neuropeptides in the brain, In: Receptors for Neurotransmitters and Peptide Hormones, pp. 407-414, Pepeu, G., Kuhar, M. J. and EnNa, S. J. (Eds.) Raven Press, New York.

WOOD, P. L., CHENEY, D. L. and COSTA. E. (1979) Modulation of the turnover rate of hippocampal acetylcholine by neuropeptides: possible site of action of $x$-melanocyte-stimulating hormone, adrenocortiotrophic hormone and somatostatin. J. Pharmacol. Exp. Ther. 209: 97-103.

Wood, P. L., Malthe-Sorenssen, D., Cheney, D. L. and Costa, E. (1978) Increase of hippocampal acetylcholine turnover rate and the stretching-yawning syndrome elicited by alpha-MSH and ACTH. Life Sci. 22 : 673-678.

Zsilla, G., Racagni, G., Cheney, D. L. and Costa, E. (1977) Constant rate infusion of deuterated phosphorylcholine to measure the effects of morphine on acetylcholine turnover rate in specific nuclei of the rat brain. Neuropharmacology 16: 25-31. 